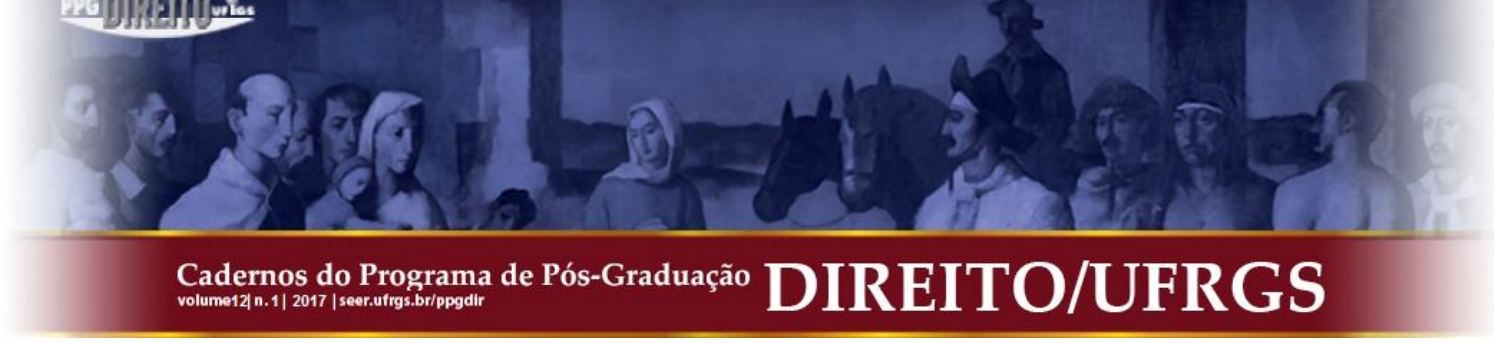

\title{
PROVÍNCIAS OU ESTADOS? AS ORIGENS DO FEDERALISMO PLATINO*
}

\author{
PROVINCES OR STATES? THE ORIGINS OF THE FEDERALISM IN THE RÍO DE LA \\ PLATA REGION
}

\section{José Carlos Chiaramonte ${ }^{* *}$}

\begin{abstract}
RESUMO: Considerar os povos platinos como soberanias independentes implica adotar uma perspectiva radicalmente distinta da historiografia atual sobre o tema; supõe considerar as habitualmente chamadas "províncias" como Estados que, desde a sua emergência até 1820 , paulatinamente lograram assumir a sua condição soberana. Obriga ainda a perguntar-se por que conservavam a denominação de províncias, denominação essa equívoca que seria uma das principais fontes de confusão no estudo das formas iniciais de Estado no Rio da Prata. Desde estas breves considerações, tem-se o propósito de justificar duas orientações analisar o uso do termo "província", integrante de um conjunto de vocábulos cruciais do vocabulário político da época, cuja utilização anacrônica é fonte de substanciais confusões; e justificar a qualidade de Estado que atribuímos às províncias platinas do período.
\end{abstract}

PALAVRAS-CHAVE: Província. Estado. Federalismo Platino. Províncias Unidas do Rio da Prata.
ABSTRACT: To consider the peoples from Río de la Plata region as independent sovereignties implies adopting a radically different perspective from the current historiography on the subject and supposes to regard the so-called "provinces" as States that, from their emergence until 1820, gradually succeeded in assuming their sovereign status. It also demands asking why it was retained the disignation of provinces, a mistaken denomination that would be one of the main sources of confusion in the study of the initial forms of State in the Rio de la Plata region. From these brief considerations, the purpose of this study is to justify two orientations - to analyze the use of the term "province", which is part of a set of crucial vocabularies of the political vocabulary of the time, whose anachronistic use is the source of substantial confusion and to justify the quality of State that we attribute to the Rio de la Plata provinces in this period.

KEYWORDS: Province. State. Federalism in Río de la Plata Region. "United Provinces of Río de la Plata".

SUMÁRIO: Introdução. 1 Primeiras Expressões do Autonomismo Comunal. 2 As Novas "Províncias" Platinas. 3 O Estado Provincial e seu Exercício da Soberania. 4 As Constituições Provinciais Platinas. 5 Independência Provincial e Governo Confederativo. 6 As Referências a um Possível Estado Platino nas Constituições Provinciais. 7 As Iniciativas Constitucionais Platinas e seu Reflexo nas Constituições Provinciais. 8 O Fracasso Constitucional de 1826 e o Avanço da Soberania e Independência Provinciais. 9 Federação ou Confederação? O Mito das Origens e a Noção de Federalismo. 10 Federação, Confederação, "Governo Nacional". 11 O Caso Rio-Platense: Confederação de

\footnotetext{
* Parte do que segue provém de texto exposto nos Cursos de Verão da Universidad Complutense de Madrid, em San Lorenzo de El Escorial, em julho de 1993, e logo incluído em: GUERRA, François-Xavier (Org.). Las revoluciones hispánicas: independencias americanas y liberalismo español. Madrid: Editorial Complutense, 1995. O texto original em língua espanhola foi publicado como capítulo de livro em: CHIARAMONTE, José Carlos. ¿Provincias o Estados? Los orígenes del federalismo rioplatense. In: CHIARAMONTE, José Carlos. Raíces históricas del federalismo latinoamericano. Buenos Aires: Sudamericana, 2016, p. 105-162. Versão do presente texto para a língua portuguesa, traduzido por Henrique Montagner Fernandes, doutorando do Programa de Pós-Graduação em Direito da Universidade Federal do Rio Grande do Sul. Revisão de tradução por Alfredo de J. Flores, Professor permanente do Programa de Pós-Graduação em Direito da Universidade Federal do Rio Grande do Sul.

Professor Honorário da Universidad de Buenos Aires (UBA), Argentina. Investigador Emérito do Consejo Nacional de Investigaciones Científicas y Técnicas, com sede no Instituto de Historia Argentina y Americana “Dr. Emilio Ravignani”, UBA/CONICET. Doutor Honoris Causa pela Universidad Nacional del Centro de la Provincia de Buenos Aires, pela Universidad Nacional de Salta e pela Universidad de Concepción del Uruguay. Diretor da coleção de História Argentina e Americana da Editoria Sudamericana. Professor visitante na Universidade Hebréia de Jerusalém, Israel, e no Departamento de Estudios Españoles y Latinoamericanos (1988). Docente de pós-graduação no Seminário de Doutorado da Faculdade de Filosofia e Letras da Universidad de Buenos Aires (1990, 1991, 1992) e no Seminário de Doutorado do Instituto Universitario Ortega y Gasset, Madrid, Espanha, 1993. Diretor de Estudos Convidado na École des Hautes Études en Sciences Sociales, Paris, França, 1994. Conferencista em reconhecidas universidades argentinas e internacionais, inclusive no Brasil. Diretor do Instituto de Historia Argentina y Americana "Dr. Emilio Ravignani" da Faculdade de Filosofia e Letras da Universidad de Buenos Aires (1986-2012).
} 


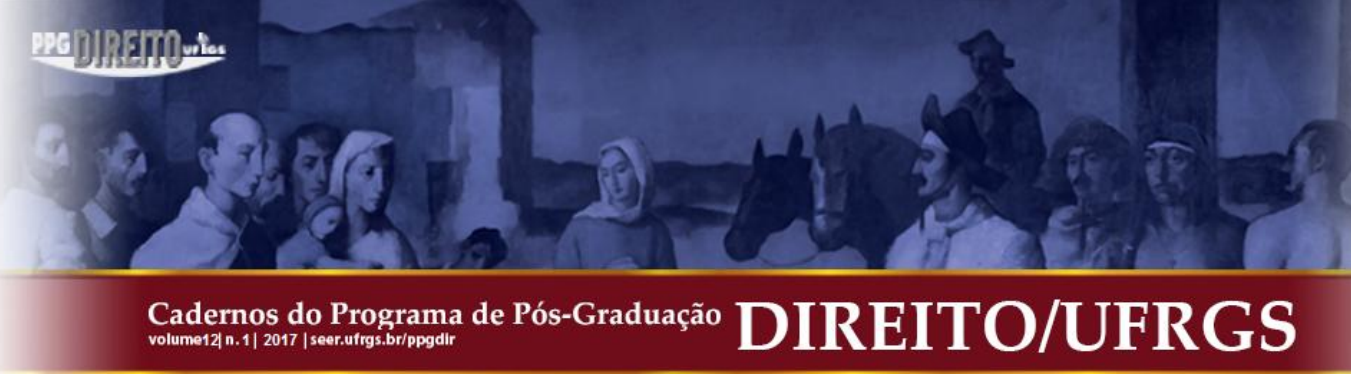

“Províncias"? 12 Testemunhos Significativos. Referências.

\section{INTRODUÇÃO}

Considerar os povos platinos como soberanias independentes, tal como faremos na sequência, implica adotar uma perspectiva radicalmente distinta da existente na historiografia sobre o tema. Ou seja, supõe considerar as habitualmente denominadas "províncias" como Estados que, desde a sua emergência até 1820, paulatinamente lograram assumir a sua condição soberana.

Da mesma forma, o fato de considerar que as províncias não eram tais - isto é, que não eram partes de um Estado superior a elas, como poderia haver sido o até então fracassado projeto de Estado nacional platino -, mas Estados independentes, obriga a perguntar-se por que conservavam a denominação de províncias. Com efeito, a denominação equívoca de província é uma das principais fontes de confusão no estudo das formas iniciais de Estado no Rio da Prata. E a resposta à pergunta recém formulada consiste em considerar que as províncias rio-platenses ${ }^{1}$ conservavam a denominação província por efeito conjugado da tradição administrativa espanhola vigente ainda no primeiro período independente - tradição na qual o termo províncias havia sido utilizado imprecisamente para se referir aos domínios de ultramar $--^{2}$, e da fugaz qualidade de províncias propriamente ditas que lhes outorgaram os breves lapsos de existência de governos centrais rio-platenses, tais como o Diretório [Directorio] ou a presidência de Rivadavia; e sem que essa denominação lhes impedisse de considerarem-se a si mesmas como Estados independentes e soberanos.

Estas breves considerações iniciais têm o propósito de justificar as duas principais orientações que seguem. Uma, a de realizar uma análise do uso do termo "província", integrante de um conjunto de vocábulos cruciais do vocabulário político da época, cuja utilização anacrônica é fonte de substanciais confusões. Outra, a de justificar a qualidade de Estado [estadidad] que atribuímos às províncias platinas do período.

\footnotetext{
${ }^{1}$ Nota de tradução: O uso do termo "rio-platense", mais fiel à linguagem utilizada pelo autor no original em espanhol, faz-se presente algumas vezes nessa tradução, como sinônimo de "platino", termo esse de ampla utilização em língua portuguesa para designar o território e a cultura que se vinculam ao antigo Vice-reinado do Rio da Prata

${ }^{2}$ Vide ALTAMIRA Y CREVEA, Rafael. Diccionario castellano de palabras jurídicas y técnicas tomadas de la legislación indiana. México D. F.: Instituto Panamericano de Historia y Geografía, 1951, p. 256 et seq.
} 


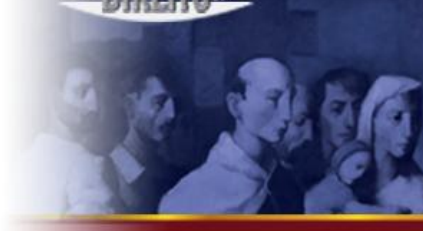

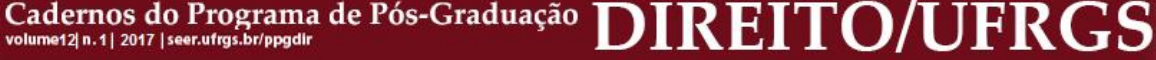

O uso recém comentado de província - em sentido mais político - possui uma sinonímia no plural povos [pueblos], que aparece com maior frequência que aquele para referir o sujeito da soberania:

[...] Este Intendente Sanz trata de fazer a liga contra os direitos dos Povos, e contra o plano de Buenos Aires. Convocou aos demais Intendentes das Províncias. [...] Dizse assim que Sanz, bem como seu Cabildo, escreveu a Lima expressando que aquele Povo estava contente em separar-se de sua Capital Buenos Aires ${ }^{3}$.

É de se notar a conotação política de tal termo, posto que o "povo" ou os "povos" são os sujeitos políticos soberanos, qualidade que alcança o uso de província quando cumpre funções de sinônimo. Todavia, o termo povo (pueblo) possui um sinônimo mais cabal e não ocasional - como o de província - no termo cidade (ciudad), correspondente ao que foi, na realidade, o núcleo inicial da formação dos novos Estados platinos ${ }^{4}$.

$\mathrm{Na}$ verdade, um dos casos mais notáveis das variações no uso de certos termos-chave nesta época de renovação política convulsiva é este do vocábulo povo. Dois de seus significados se sobressaem por sua referência a dois conceitos historicamente distintos e adversos de soberania. Um deles, cuja aparição se dá muito frequentemente no uso do vocábulo no plural [pueblos], refere, em termos políticos próprios do antigo regime espanhol, às cidades às quais se supõe que se tenha revertido a soberania anteriormente imputada ao monarca espanhol. Já na forma singular [pueblo], por outro lado, às vezes costuma-se utilizar para referir ao povo soberano, no sentido da doutrina moderna da soberania popular; sua aparição mais frequente na imprensa de Buenos Aires corresponde ao breve período de predomínio do grupo morenista liderado, depois da morte de Moreno, por Bernardo de Monteagudo, apesar de não desaparecer por completo nos anos posteriores. Um artigo da

\footnotetext{
${ }^{3}$ ALTAMIRA Y CREVEA, Rafael. op. cit., p. 256. No mesmo local: "(...) Fulminou-se por excomunhão política para que os habitantes desses povos não sejam infestados ou contagiados pelos de Buenos Aires (...)". Da mesma forma: "(...) porém, creio firmemente que serão vãos seus esforços, e que terá à satisfação de muito em breve anunciar a V. E. a liberdade de povos que não merecem ter por cabeça uns tiranos que só consultam sobre a própria fortuna (...)" (p. 242).

${ }^{4}$ Ocupamo-nos do tema pela primeira vez em: CHIARAMONTE, José Carlos. Ciudad, provincia, nación: las formas de identidad colectiva en el Río de la Plata colonial. Actas del III Congreso Argentino de Hispanistas "España en América y América en España". Tomo 1. Buenos Aires: Instituto de Filología Hispánica "Amado Alonso", Facultad de Filosofía y Letras - U.B.A., 1993. Também cabe recordar que, na tradição jurídica castelhana, o vocábulo povo (pueblo) compreendia cidades, vilas e lugares. Ver, por exemplo, a NOVÍSIMA Recopilación de las Leyes de España (Libro VII, Título III, Ley I e Ley VII; Título IV, Ley I e Ley II). Los códigos españoles concordados y anotados. 2. ed. Tomo VIII. Madrid: A. de San Martín, 1872, p. 353-355. Ver também: PETIT MUÑOZ, Eugenio. Artigas y su ideario a través de seis series documentales. Primera Parte. Montevideo: Universidad de la República Oriental del Uruguay, Facultad de Humanidades y Ciencias, 1956.
} 


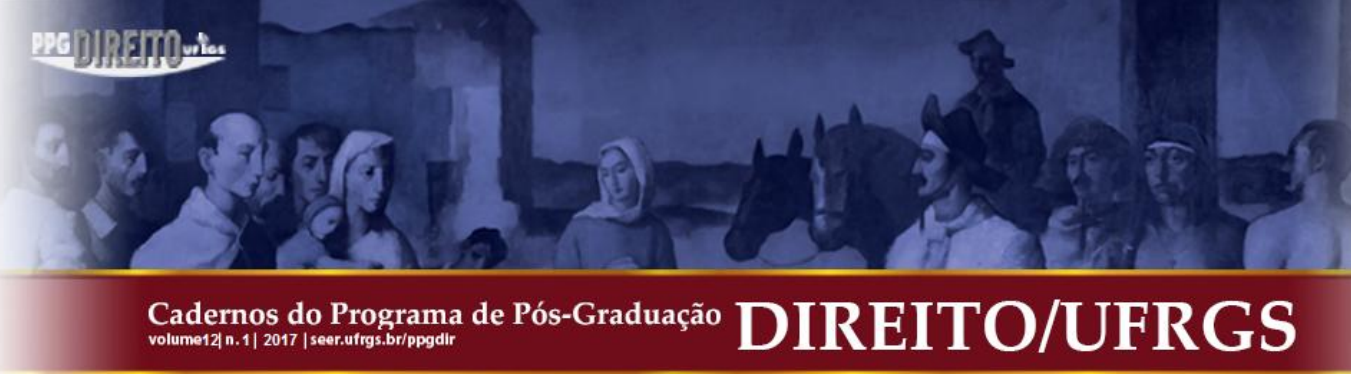

América, a soberania deverá ser exercida mediante a criação de um novo poder, cuja qualidade política e extensão territorial serão motivo de disputa imediata.

Porém, previamente à consideração de tais questões, cabe perguntar-se que entidade real tinha o novo soberano. A resposta é dada pelas mesmas decisões inaugurais do processo da Independência: quem havia reassumido a soberania e quem a exerce em busca da instituição de um novo poder são os povos, isto é, as cidades, cujos órgãos de gestão - os Cabildos - de pronto passam a converter-se em órgãos representativos do novo soberano, transformação preparada pela figura do cabildo abierto surgida nos últimos anos do regime colonial. A necessidade de conciliar as soberanias de todos os povos de um Vice-reinado conduz de imediato à constituição de Juntas, no estilo espanhol daqueles anos.

Assim, no âmbito da cidade, estrutura-se a primeira forma legítima do novo poder, conquanto paralelamente os governos centrais, isto é, aqueles que pretendem substituir as autoridades vice-reinais, desde a Primeira Junta em diante, verão problematizada, desde os seus primeiros momentos de existência, a sua legitimidade - ao ter nascido de uma decisão unilateral de uma só das cidades soberanas - que buscarão sem muito êxito fundá-la em bom direito. Enquanto isso, exercerão de fato esse poder cujos fundamentos não poderão ser legitimados enquanto os povos soberanos não o convalidarem por sua incorporação como soberanias independentes, e mediante deputados que possuíssem o antigo caráter de apoderados.

De tal maneira, o primeiro âmbito do novo poder soberano e sua primeira forma estatal legítima é a cidade. Com ela, postula-se uma nova forma de poder, um novo Estado possível, com dimensões territoriais imprecisas, porém tendentes a abarcar o espaço do velho Vice-reinado ou, ao menos, a maior parte dele. Estado esse cuja legitimação e consolidação serão buscadas de forma infrutífera ao longo da primeira metade do século. Enquanto isso, aos poucos, os povos soberanos passarão a instituir-se como províncias: em parte por necessidade de afirmação de sua presença política no cenário platino; em parte pela emergência política de cidades subordinadas e de zonas rurais que até então integravam a jurisdição de uma cidade, mas tendiam a uma representação mais específica; em parte pela

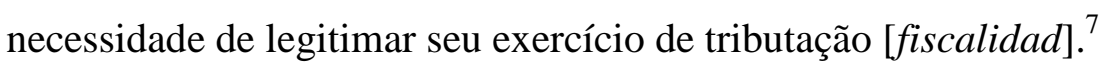

\footnotetext{
${ }^{7}$ Um parágrafo da primeira lei promulgada pelo novo Estado correntino oferece um exemplo do critério político tradicional predominante na época: "A Província é composta de todos os povos compreendidos no território de sua imemorial e ininterrupta possessão (...)” (REGISTRO Oficial de la Provincia de Corrientes. Ley n 1, 26/XI/1821. 
O Regulamento de 10 de fevereiro de 1811 para a formação de Juntas provinciais e Juntas subordinadas tentava reorganizar a estrutura provincial herdada do regime de intendências para adaptá-la às novas formas de exercício do poder, porém mantendo as províncias até então existentes. Com tal propósito, criava as mencionadas Juntas e estabelecia que as principais seriam compostas de cinco membros: o Gobernador Intendente, eleito pela Junta de Buenos Aires, e quatro vogais, eleitos em eleições populares de segundo grau. As Juntas subordinadas se compunham de três membros: o comandante de armas, que a presidia, e dois sócios eleitos pelo povo ${ }^{8}$.

O Regulamento provocou uma luta entre os Cabildos, que queriam ter as Juntas sob seu controle, e estas, que, com outra composição, dada a qualidade diversa do corpo eleitoral do qual surgiam, resistiam a esse controle ${ }^{9}$. Porém, da mesma forma, deu vez a um conflito de maior transcendência ao colidir com as pretensões autonômicas das cidades subordinadas. Antes mesmo de conhecer o Regulamento, a 11 de fevereiro de 1811, o Cabildo da cidade de Jujuy solicitava a autonomia de sua cidade em relação à de Salta, da qual dependia, segundo o regime de intendências ainda vigente, e propunha um conjunto de normas para regular a sua relação com a Junta de Buenos Aires e as outras cidades do território rio-platense. Em dezoito artigos que poderiam ser interpretados como uma antecipação rústica da série constitucional provincial posterior a 1819, defendeu “a Independência que Jujuy solicita quanto à Intendência de Salta" ${ }^{\prime 10}$. O Cabildo de Jujuy criticava duramente o fato de que, desde a “fundação destas Américas”, não houvesse uma só Província com um corpo de legislação particular. De maneira que, declarava, utilizando da liberdade que o novo governo estabeleceu para que cada povo manifestasse seu entendimento, havia decidido propor: " $1{ }^{\circ}$ Que no novo Sistema de Governo, esta Cidade, com o território de sua Jurisdição, restituindo-se a recém-

Tomo I, [s.d], p. 15). Observamos nesse texto, de um lado, que a referência às unidades políticas que compõem a província não é o povo - enquanto conjunto de cidadãos -, mas aos povos. Igualmente, que está ausente qualquer referência à campanha, cujas pretensões políticas conduziram à reforma constitucional de 1824 . Ver, a esse respeito, nosso trabalho: CHIARAMONTE, J. C. Legalidad constitucional o caudillismo: el problema del orden social en el surgimiento de los estados autónomos del Litoral argentino en la primera mitad del siglo XIX. Desarrollo Económico, Buenos Aires, v. 26, n. 102, jul.-set. 1986.

${ }^{8} \mathrm{O}$ regulamento está incluído na "Orden del Día” publicada na GAZETA de Buenos-Ayres. 14 de fevereiro de 1811, p. 549-553.

${ }_{9}^{9}$ LEVENE, Ricardo. Las Provincias Unidas del Sud en 1811 (Consecuencias inmediatas de la Revolución de Mayo). Buenos Aires: Universidad de Buenos Aires, 1940, p. 17.

10 "'El Cabildo de Jujuy a la Junta de Buenos Aires exponiendo las reformas a adoptarse en el nuevo sistema, 19 de Febrero de 1811]", disponível em: LEVENE. op. cit., 1940, p. 149. 


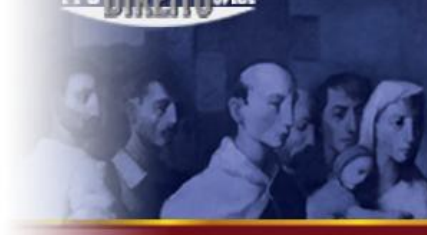

criada Subdelegação da Fazenda de Rinconada, devesse ser reputada uma pequena república que governa a si mesma".

E reivindicava a independência de Jujuy em relação à ciudad cabecera: " $4^{\circ}$ Por conseguinte, deve abolir-se a dependência dos Intendentes de Salta, e, em seu lugar, criar-se um Pretor que nesta Cidade tenha as mesmas faculdades, ou, melhor dizendo, desempenhe todas as funções atribuídas aos Intendentes”.

Ao comentar esses artigos, o Cabildo expressa que, se todas as cidades solicitassem o mesmo, longe de ver-se afetado, sentir-se-ia muito feliz ${ }^{11}$.

A petição do Cabildo de Jujuy foi reiterada por seu deputado na Junta de Buenos Aires, José Ignacio Gorriti, em ao menos duas representações sucessivas, datadas em 4 de maio e 19 de junho de 1811. Elas foram publicadas por Ricardo Levene, que erroneamente as converte em peças iniciais do federalismo platino ${ }^{12}$, não obstante lhes caiba a mesma observação recém apontada quanto ao escrito do Cabildo de Jujuy. Ademais, longe de propugnar o federalismo, Gorriti o rechaça expressamente e sublinha os laços de subordinação ao poder central dessas cidades cuja autonomia recíproca ele reclama:

\begin{abstract}
Não vejo, repito, um só inconveniente para que cada cidade se entenda diretamente com esta Junta superior, sem que necessitem de uma mão intermediária: e assim seus assuntos circulam com rapidez e experimentam as vantagens do atual sistema. Por que não lograrão igual sorte todas as demais Cidades, se todas têm direitos iguais? Poder-se-á objetar que vamos tangenciar o Sistema federativo; porém, eu respondo que vamos estreitar e fortificar a união de todo o Corpo do estado com o governo supremo constituído pelos mesmos povos. Este se torna o centro da unidade: o ponto único onde todas as relações de cada povo deságuam ${ }^{13}$.
\end{abstract}

\footnotetext{
${ }^{11}$ LEVENE. op. cit., 1940, p. 150. O terceiro artigo também parece conceber o regime proposto como de cidades em pé de igualdade: " $3{ }^{\circ}$ Que cada Cidade jure amizade, mútuo socorro e perfeita irmandade com as demais do Reino".

12 "[Escritos del Diputado de Jujuy Juan Ignacio de Gorriti, de fechas 4 de mayo y 19 de junio de 1811, exponiendo los graves males que entraña la aplicación del decreto sobre creación de Juntas provinciales y subalternas. Borrador de réplica del deán Funes a sus argumentos]" em: LEVENE. op. cit., 1940, p. 204 et seq. Vejam-se os argumentos insustentáveis de Levene, interpretando esses textos como expressões federativas (p. 7 et seq.). Com esta interpretação, mais a que faz de Mariano Moreno como outro federalista, Levene parece querer competir com a historiografia uruguaia e argentina que bastante razoavelmente considera que a série documental federalista se inicia com os textos de Artigas, de 1813, encontrando antecedentes argentinos anteriores aos artiguistas: "Como se sabe, nas importantes 'Instruções' de Artigas, do ano de 1813, entre outras questões foi levantada a da federação. Porém, tal problema político do federalismo havia se exteriorizado em 1810 e desenrolado em sua extensão em 1811, como fica demostrado documentalmente neste trabalho. É que um dos fins essenciais da Revolução de Maio é o federalismo" (LEVENE. op. cit., 1940, p. 31).

${ }^{13}$ Juan Ignacio de Gorriti à Junta de Buenos Aires, Buenos Aires, 4 de maio de 1811, em: LEVENE. op. cit., 1940, p. 211. Previamente a esse trabalho, Levene havia tratado o assunto em termos similares em artigo (LEVENE, Ricardo. Los primeros documentos de nuestro federalismo político. Humanidades, t. XXIII, La Plata, 1933), que incluía como apêndice alguns dos documentos da edição posterior, entre eles os de Jujuy. Vide também, a crítica de Juan Canter a essa primeira formulação do critério de Levene em: CANTER, Juan. Una interesante carta de Pueyrredón. Boletín del Instituto de Investigaciones Históricas, Buenos Aires, t. XVII, n. 58-60, 1934, p. 440, nota. Tampouco Canter 
A demanda de Jujuy não foi a única do período. Ela começa uma querela das cidades subordinadas para conquistar sua autonomia em relação às que eram capitais de intendência ou, logo da promulgação do Regulamento, que eram sede das Juntas principais. Assim, Mendoza reclama sua independência de Córdoba em "Representação à Junta de Buenos Aires" na data de 10 de julho de 1811. Outras cidades, como Tucumán e Tarija, aderiram à postura de Jujuy. ${ }^{14}$ Esta tendência persistirá para além da vigência do Regulamento de $1811 \mathrm{e}$ levará a que catorze províncias ocupem o lugar das três originais do regime de Intendências Buenos Aires, Córdoba del Tucumán e Salta del Tucumán, as três cujos territórios permaneceriam no futuro Estado argentino, das oito que integravam o Vice-reinado do Rio da Prata.

\section{AS NOVAS "PROVÍNCIAS” PLATINAS}

A primeira decisão relativa à criação de províncias posterior à revolução de Maio de 1810 foi a resolução do Triunvirato, de novembro de 1813, a qual separava os povos de Mendoza, San Juan e San Luis do "governo-intendência” de Córdoba, e com eles criava “(...) um Governo Intendência à parte com a antiga denominação de Província de Cuyo (...)”.

Ou seja, um ato que se expressava ainda na linguagem administrativa do antigo governo espanhol. Da mesma forma, sucessivos decretos do Director Posadas, de março, setembro e outubro de 1814, criavam a Província Oriental do Rio da Prata, as províncias de Entre Ríos e Corrientes, separando seus territórios da Intendência de Buenos Aires, e as províncias de Salta e de Tucumán, com "povos" e "cidades" - vocábulos usados indistintamente -, que até então haviam pertencido à Intendência de Salta del Tucumán ${ }^{15}$.

As novas entidades políticas assim criadas por disposições oficiais, ou por decisão própria de segregarem-se de outras províncias - tal como o haviam feito Santa Fe em 1818, Santiago del Estero em 1820, ou Jujuy em 1834 -, ingressavam em um status indefinido;

melhorava muito o tratamento do assunto, pois sustentava ainda mais obstinadamente do que Levene que "o que é simples localismo para Levene se torna federalismo", agregava que o federalismo nasce das Intendências.

${ }^{14}$ LEVENE. op. cit., 1940, p. 18. Levene toma o dado relativo a Tucumán e Tarija de Joaquín Carrillo (CARRILLO, Joaquín. Jujuy, Provincia federal argentina. Apuntes de su historia civil. Buenos Aires: Impr. del Mercurio, 1877).

${ }^{15}$ REGISTRO Oficial de la República Argentina. Tomo I, 1810 a 1821. Buenos Aires, 1879, p. 241, 265,283 e 288. Ver, também: GONZÁLEZ CALDERÓN J. A. Introducción al derecho público provincial. Buenos Aires: Lajouane, 1913, p. 19 et seq. 


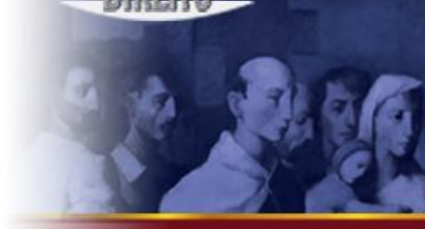

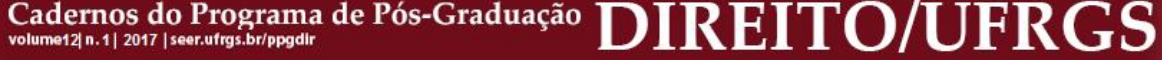

constituíam-se, pois, como províncias, enquanto supostas partes de um Estado que, além de congregar em seus fugazes períodos de existência os povos de um também impreciso território platino, careceu de existência real durante a maior parte dos anos entre 1810 e 1831, e cuja projetada Constituição, a partir do último desses anos, seria largamente postergada pela emergência de uma "leve" união confederativa em seu lugar. Aquela indefinição tendeu a ser superada, não sempre com êxito, quando à raiz do fracasso do intento constitucional de 18161819, diversas províncias começaram a afirmar constitucionalmente sua soberania e independência.

A partir de uma interpretação usual do caudilhismo latino-americano - observávamos em um trabalho anterior ${ }^{16}$ - poder-se-ia julgar que o surgimento dos Estados provinciais seria uma fachada artificial para recobrir uma situação de domínio privado - o do caudilho sobre as riquezas e homens que controla - gestada no seio de relações sociais pouco desenvolvidas, em vez de focá-lo como parte dos fenômenos gerados por sociedades com necessidade de se conferirem uma organização estatal. Acrescentávamos, também, que a inclinação - tanto de observadores do século passado que nos deixaram algum testemunho dessas sociedades, especialmente dos viajantes europeus, quanto de historiadores contemporâneos - ao uso de termos condenatórios como "déspota", "selvagem", "barbárie”, “ditador", “feudal”, pode induzir a erro na apreciação do real grau de legalidade existente nessas sociedades provinciais platinas. Referíamo-nos assim à intenção, mais metafórica do que conceitual, subjacente à aplicação desses termos a diversos aspectos das sociedades provinciais que, como o uso da força armada e as modalidades cruentas desse uso, foram uma de suas características permanentes ${ }^{17}$.

Porém o certo é que também nos casos de existência de aparentes formas de facto de exercício do poder, tinha vigência um ordenamento legal mais extenso do que aquele que se costuma supor $^{18}$, do que dão conta a organização fiscal das províncias, sua regulação do comércio exterior, sua organização militar, o exercício do patronato, as faculdades de

\footnotetext{
${ }^{16}$ Ver: CHIARAMONTE. op. cit., 1986.

${ }^{17}$ Sobre o uso de tais termos, ver nosso comentário em: CHIARAMONTE. Formas de economía y sociedad en Iberoamérica. México: Grijalbo, 1984, p. 52 et seq.

${ }^{18}$ Ver: GOLDMAN, Noemí. Legalidad y legitimidad en el caudillismo. Juan Facundo Quiroga y La Rioja en el Interior rioplatense (1810-1835). Boletín del Instituto de Historia Argentina y Americana "Dr. Emilio Ravignani", $3^{\mathrm{a}}$ série, n. 7, 1993. Uma revisão atualizada do tema pode ser encontrada no meu artigo: CHIARAMONTE, J. C. The “Ancient Constitution" after the Independences (1808-1852). American Historical Review, v. 90, n. 3, ago. 2010. E a versão em espanhol do mesmo artigo: CHIARAMONTE, J. C. La antigua Constitución luego de las independencias, 1808-1852. Desarrollo Económico, Buenos Aires, v. 50, n. 199, out.-dez. 2010.
} 


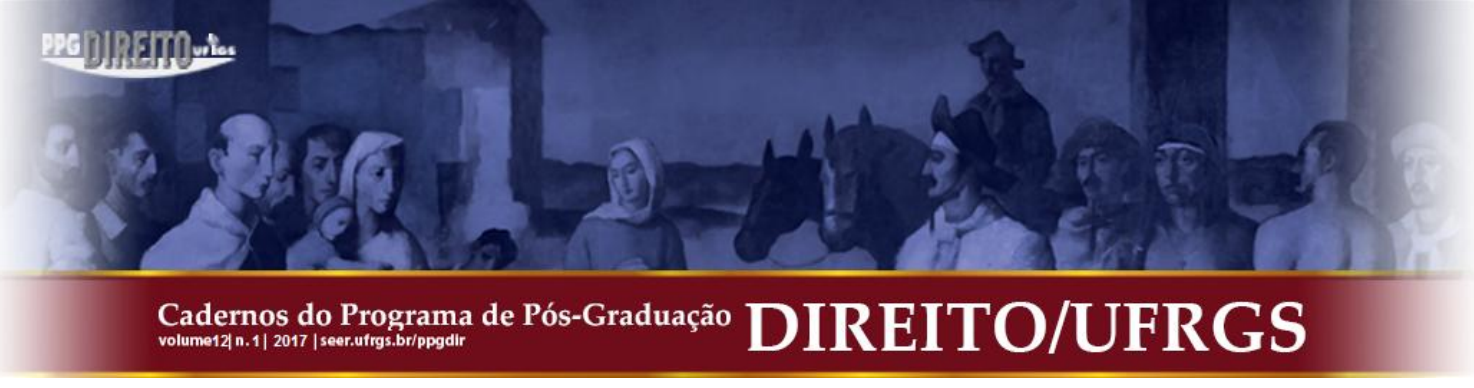

cunhagem de moeda [amonedación], a regulação do sistema de pesos e medidas, e diversas normas legislativas e políticas; entre estas, a legitimação de determinada prática jurídica, embora regida pelo direito espanhol. Esse ordenamento legal buscou, salvo exceções, fundarse em textos constitucionais, cuja aparição precoce e difusão generalizada na região platina configuram um fenômeno significativo da época.

Todos esses traços testemunham o caráter de Estado independente que as elites provinciais decidiram designar ao novo organismo que fundavam, logo do fracasso da tentativa de constituir um Estado platino, em 1819. Para examinar esta característica, propomos ocupar-nos, na sequência, de alguns aspectos do ordenamento jurídico-político que as províncias se conferiram para, após, passar a outros traços conformadores de suas pretensões estatais.

\section{O ESTADO PROVINCIAL E SEU EXERCÍCIO DA SOBERANIA}

Se nos ativéssemos apenas às províncias que posteriormente integraram a República Argentina, poderíamos julgar que o Estatuto Constitucional Provisório da Província de Santa Fe inicia, em 1819, a série de Constituições provinciais. Porém, se consideramos o conjunto das províncias ou "povos" platinos que então gestavam sua possível integração estatal, há um texto anterior ao de Santa Fe. Uma Constituição que, se bem não chegou a ter vigência, possui especial significado porque forma parte de um conjunto de documentos políticos que influíram profundamente no constitucionalismo provincial argentino. Trata-se da “constituição territorial” da Banda Oriental, documento artiguista de $1813^{19}$.

Em primeiro lugar, para nosso propósito, nesse projeto constitucional interessa-nos comprovar que a postulação de um Estado provincial era formulada como criação de uma província, a "Província Oriental do Uruguai". Isso se fazia explícito ao declarar-se que a Constituição era redigida para “(...) o povo que ocupa o território anteriormente chamado Campaña Oriental, e que, por meio da presente, acorda, solene e mutuamente com cada um

\footnotetext{
${ }^{19}$ Este projeto constitucional esquecido foi descoberto no século passado em arquivos da Espanha e divulgado por Emilio Ravignani em 1929 (RAVIGNANI, E. Un proyecto de Constitución relativo a la autonomía de la Provincia Oriental del Uruguay, 1813-1815. Buenos Aires: Impr. de la Universidad de Buenos Aires, 1929). O projeto artiguista se inspira na Carta do Estado de Massachussets, na tradução de García de Sena, conforme Alberto Demicheli (DEMICHELI, A. Formación constitucional rioplatense. Tomo II. Montevideo, 1955, Cap. XIII, "La Constitución territorial de la Provincia Oriental”, p. 561 et seq.).
} 


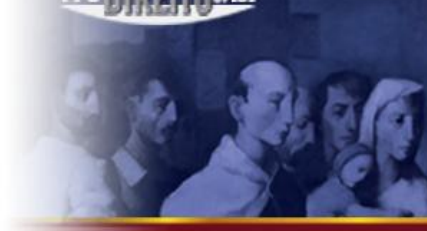

dos outros, formar o mesmo num Corpo Político, ou Província livre, Soberana e Independente, com o nome de Província Oriental do Uruguai”,20.

Por outro lado, esta definição de uma província "livre, soberana e independente" fórmula inspirada nos "Artigos de Confederação" norte-americanos ${ }^{21}$ - adota uma figura política que seria utilizada pelos textos constitucionais de outras províncias platinas, as quais, ao assim proceder, continuariam, com poucas exceções, a paradoxal conjugação do caráter dependente sugerido pelo termo "província" com a afirmação de sua independência e soberania. Nisso, como em outros aspectos de sua articulação, a Constituição oriental seguia as famosas Instruções artiguistas de 1813, das quais convém aqui transcrever alguns dos artigos eu nos interessam a fim de observar a aparição do Estado provincial como um Estado independente:

art. 21. Não admitir-se-á outro sistema que o da Confederação para o pacto recíproco com as Províncias que formam nosso Estado.

art. 81. O território que estes povos ocupam, desde a costa oriental do Uruguai até a Fortaleza de Santa Teresa, formam uma só Província, denominada de Província Oriental.

art. 10. Que, pela presente, esta Província ingressa separadamente em uma firme liga de amizade com cada uma das outras, para sua defesa comum, garantia de sua liberdade e para sua mútua e geral felicidade (...) etc.

art. 11. Que esta Província retém sua soberania, liberdade e independência, todo poder, jurisdição e direito que não seja expressamente delegado pela Confederação às Províncias unidas juntas em congresso.

art. 16. Que esta Província terá a sua Constituição territorial; e que ela tem o direito de sancionar a [Constituição] geral das Províncias Unidas que forme a Assembleia Constituinte.

art. 17. Que esta Província tem direito a levantar os regimentos que necessite (...) etc $^{22}$.

\footnotetext{
${ }^{20}$ Art. 1, cap. 2. (DEMICHELI. op. cit., Tomo I, p. 174).

21 "Cada Estado conserva sua soberania, liberdade e independência, assim como todo seu poder, jurisdição e direito não delegados expressamente por esta Confederação aos Estados Unidos quando atuem por meio de seu Congresso" (Art. II dos Artigos de Confederação (...). HAMILTON, Alexander; MADISON, James; JAY, John. El Federalista. México: F.C.E., 1974, Apêndice II). A mesma fórmula era usada em um "Projeto de Constituição de caráter federal para as Províncias Unidas da América do Sul": "Cada província retém sua soberania, liberdade, ou independência, e todo poder, jurisdição e direito que não seja delegado expressamente por esta confederação às Províncias Unidas juntas em Congresso" (ARTÍCULOS de confederación y perpetua unión entre las provincias de Buenos Aires, Santa Fe, Corrientes, Paraguay, Banda Oriental del Uruguay, Córdoba, Tucumán, etc. In: RAVIGNANI, Emilio (Org.). Asambleas Constituyentes argentinas. Tomo VI, Segunda Parte. Buenos Aires: Instituto de Investigaciones Históricas de la Facultad de Filosofía y Letras - UBA, 1937, p. 633, art. 2.

${ }^{22}$ Tomamos o texto das "Instrucciones" insertado em: PETIT MUÑOZ, Eugenio. op. cit., p. 224. Na realidade, houve três textos dessas Instruções. As de 5 de abril, aprovadas pelo Congreso de Tres Cruces nesse dia e enviadas às demais províncias rio-platenses (há registro de que Santa Fé as recebeu: DEMICHELI, Alberto. op. cit., Tomo II, p. 222); as de Artigas, de 13 de abril; e as de Soriano, de 18 de abril. Segundo Demicheli, as de Artigas seriam anteriores. Há várias diferenças entre os textos: DEMICHELI, Alberto. op. cit., Tomo II, p. 338.
} 


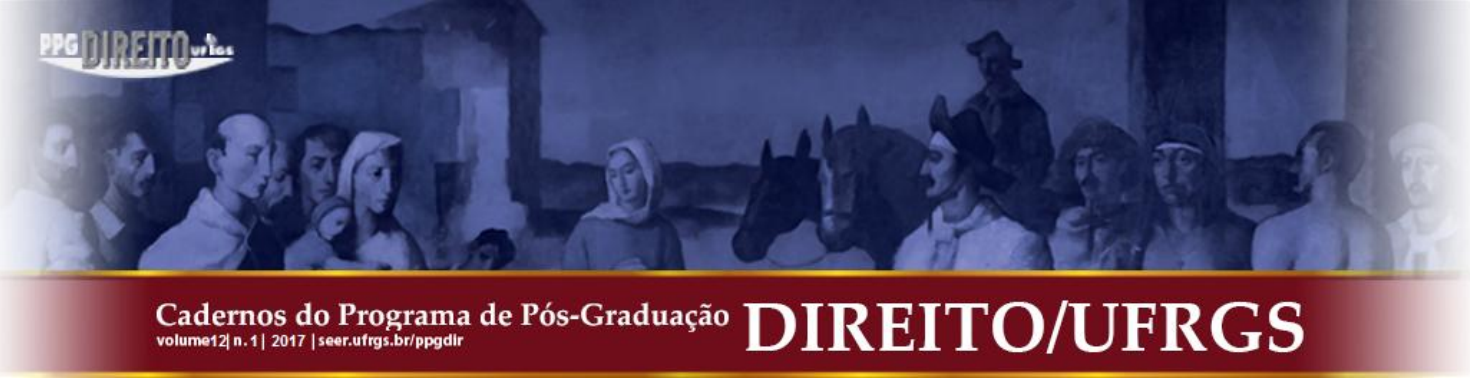

As Instruções artiguistas foram enviadas aos outros "povos" platinos e não podiam deixar de ser conhecidas por aqueles que redigiriam as constituições platinas. Porém, uns e outros documentos remetem também aos antecedentes confederais que o público letrado hispano-americano conhecia por meio dos tratadistas políticos do século XVIII. Com efeito, basta comparar o citado artigo 11 das Instruções com o já citado artigo $2^{\circ}$ dos "Artigos de Confederação e União Perpétua...” dos Estados norte-americanos. Só que convém reforçar que esta afirmação similar de independência e soberania era formulada como correspondente a uma província e não a um Estado, como no caso norte-americano.

\section{AS CONSTITUIÇÕES PROVINCIAIS PLATINAS}

Após o novo fracasso da tentativa de organização constitucional platina, em 1819, esses textos constitucionais irão legalizando a situação de fato emergente desses fracassos: a de as sociedades provinciais serem a única dimensão capaz de sustentar-se sem desmembramentos e apta para tornar viável o propósito de fundar uma ordem social e uma organização do poder relativamente estáveis. De outra parte, na medida em que crescia a percepção das dificuldades quanto à organização confederativa dessas províncias, a natureza estatal independente da província-Estado não pode senão acentuar-se, como comprovaremos mais adiante no caso de duas delas que reformaram suas Constituições no final do período de que nos ocupamos ${ }^{23}$.

Esta série constitucional merece uma consideração mais extensa do que a motivada, seja pelo espírito provincial laudatório, seja por um interesse técnico constitucionalista. Nesse segundo caso, em que pese a presumível maior objetividade, costuma prevalecer o propósito de julgar os méritos jurídico-políticos desses textos ${ }^{24}$, bem como predomina a suposição de

\footnotetext{
${ }^{23}$ A maior parte dos textos constitucionais mencionados em nosso trabalho, tomamos de: RAMOS, Juan P. El Derecho Público de las provincias argentinas, con el texto de las constituciones sancionadas entre los años 1819 y 1913. Tomo I. Buenos Aires: Facultad de Derecho y Ciencias Sociales, 1914; RAMOS, Juan P. El Derecho Público de las provincias argentinas, con el texto de las constituciones sancionadas entre los años 1819 y 1913. Tomo II. Buenos Aires: Facultad de Derecho y Ciencias Sociales, 1916; RAMOS, Juan P. El Derecho Público de las provincias argentinas, con el texto de las constituciones sancionadas entre los años 1819 y 1913. Tomo III. Buenos Aires: Facultad de Derecho y Ciencias Sociales, 1916. Outros, não incluídos nessa obra, foram publicados por Emilio Ravignani no tomo VI das referidas Asambleas Constituyentes...: a constituição de Salta, de 1821, o projeto constitucional do mesmo ano para os "povos unidos de Cuyo", o Regulamento de Santiago del Estero, de 1830, e o Projeto da mesma província, de 1835.

${ }^{24}$ Ver a crítica pejorativa de Juan P. Ramos (RAMOS, Juan P. op. cit., Tomo I, Capítulo II - "Las constituciones provinciales", p. 68 et seq.).
} 


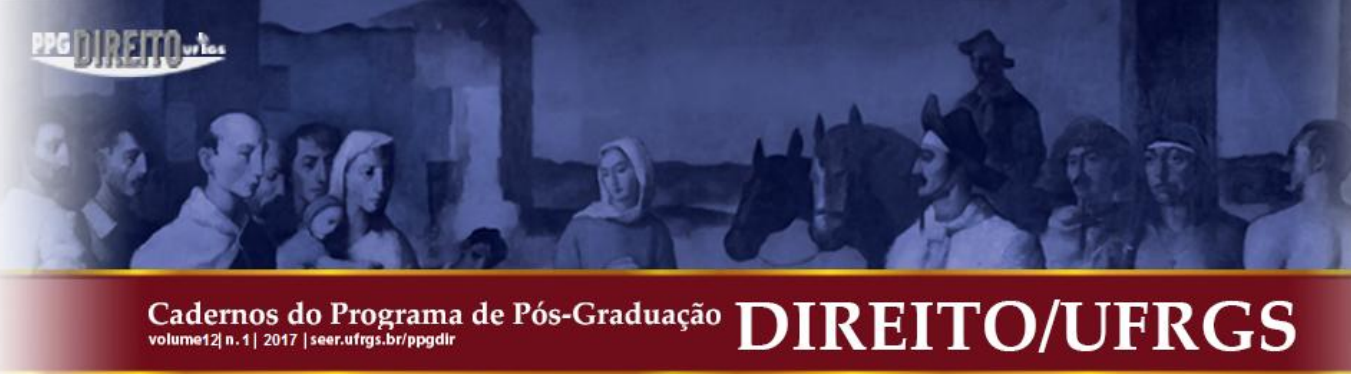

uma nação já existente. Nossa pretensão, para além da maior ou menor qualidade jurídica dessas Constituições, é examiná-las como expressão do apontado mais acima. Ou seja, em primeiro lugar, observar que, por si mesmos e por sua afirmação geral de liberdade, independência e soberania, esses textos marcam a substituição do intento constitucional de dimensões platinas por outros limitados ao âmbito provincial. Porém, ao mesmo tempo, advertir que refletem das tentativas supraprovinciais anteriores, os de 1813 e 1816-1819, a tendência a uma Constituição escrita prévia à organização estatal. Isto é, que testemunham a adoção do caminho norte-americano e francês, oposto na polémica da época ao exemplo britânico de prescindir de Constituições escritas e deixar ao tempo a obra de gestar as leis fundamentais de uma sociedade, caminho este que haverá de ser seguido pela província de Buenos Aires, que, junto com as de Mendoza e La Rioja, carecerá de Constituição durante o período. Assim, fossem caudilhos ou grupos políticos os que se preparavam para preencher o vácuo de poder no reduzido âmbito de sua província, compartilhavam a pretensão de fundar a legitimidade desse poder em um texto constitucional.

\section{INDEPENDÊNCIA PROVINCIAL E GOVERNO CONFEDERATIVO}

Diversa é a forma que cada texto constitucional provincial expressa a relação entre a soberania e a independência da província e a possibilidade de integrar um Estado superior a elas. Alguns, como o mencionado de Santa Fe, o de Corrientes, de 1824, ou o de Santiago del Estero, de $1832^{25}$, ignoram qualquer outra realidade estatal que não seja a provincial, e assumem todas as funções que eram consideradas "nacionais", como a guerra, o comércio exterior, relações com a Igreja, e demais. Outras dessas Constituições condicionam a validade do legislado a decisões de um congresso ou governo, em alguns casos chamado de nacional, em outros de federal ou confederativo. Porém, essa reserva em favor de um possível governo supraprovincial, que, a seu turno, não possui a mesma força em todos os casos, é de substância confederativa, substância congruente com a afirmação de independência e soberania do Estado provincial.

\footnotetext{
${ }^{25}$ REGLAMENTO para la organización política de la provincia de Santiago del Estero (...), 26 de julio de 1830. In: RAVIGNANI, Emilio (Org.). Asambleas Constituyentes Argentinas. Tomo VI, Segunda Parte. Buenos Aires: Instituto de Investigaciones Históricas de la Facultad de Filosofía y Letras - Universidad de Buenos Aires, 1937, p. 1134. O único traço de possível alusão a um poder supraprovincial poderia ser encontrado na limitação que as palavras "por agora" do artigo primeiro implicam: "A Soberania reside essencialmente por agora na Província (...)”.
} 


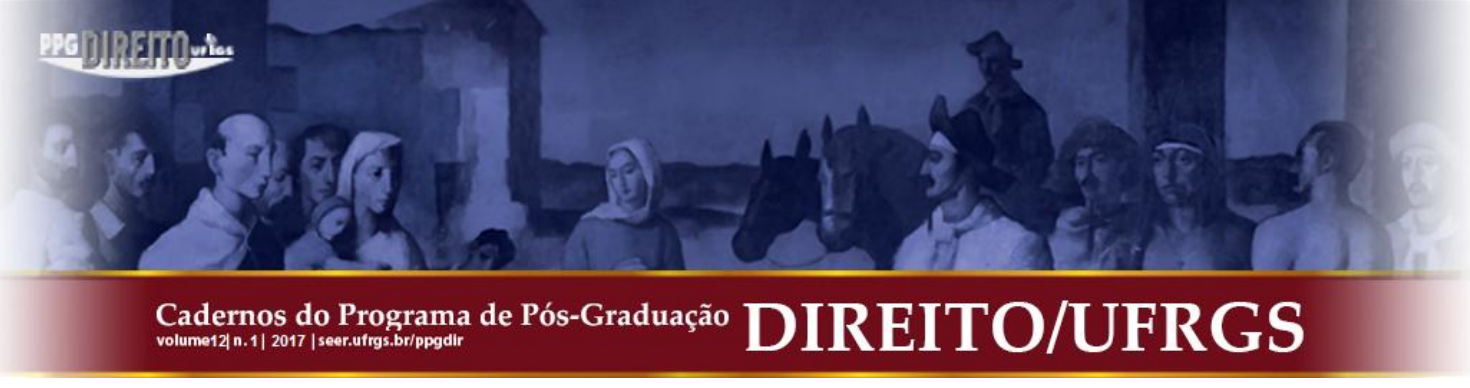

No caso do "Estatuto provisório da província de Santa Fe", promulgado por Estanislao López a 26 de agosto de 1819, apenas um rudimento de Constituição, ${ }^{26}$ isso reveste aspectos abertamente paradoxais, porquanto em um breve conjunto de artigos nos quais se alude de forma confusa a funções representativas e judiciais, predomina o objetivo de conferir base legal ao exercício do poder por parte de um caudilho. Objetivo feito explícito num texto, o do artigo 19, que é excepcional - no conjunto dessas Constituições provinciais e também na literatura política da época - pelo uso do vocábulo caudilho associado a previsões de soberania popular e liberdades modernas: "Sendo um dos atos mais essenciais à liberdade do homem a nomeação de seu caudilho (...)".

Quanto à soberania, o Estatuto afirma que reside no povo e que se expressa na eleição popular da Representação da Província, constituída por oito comissários pela capital, dois pelo povo e campanha de Rosario, um pelo de Coronda e outro pelo do partido de San José del Rincón. Porém, o objeto dessa Representação se limita à eleição do Cabildo da capital e a “expedir as funções que os artigos designam”, finalizando sua missão após essas tarefas assim vagamente aludidas. Nada diz o Estatuto que possa dar a entender que essa Representação possuísse funções legislativas. Quanto ao Executivo, é de eleição direta pelo povo de cada localidade reunido na cabeça dos seus departamentos de campanha, presididos por seus comandantes, ou, nos cuarteles da capital, por um membro do Cabildo ou pelo alcalde de barrio. No mesmo ato, seriam eleitos comissários que, reunidos na capital, efetuariam o escrutínio e designariam o eleito. No tocante às funções judiciais, continuariam como até o momento, e o Governador seria a única instância de apelação para as decisões dos juízes.

De modo que o Estatuto de Santa Fe poderia ser considerado como uma sanção do poder de fato do caudilho. Nada há nele que permita supor não só um equilíbrio de poderes como também a consideração de um âmbito legislativo e outro judicial autônomos. E, por outra parte, no que diz respeito à eleição do executivo, caso se considere o método prescrito, infere-se que era muito difícil a expressão de uma tendência dissidente.

Esse Estatuto rudimentar, no entanto, define um ordenamento legal que não deixará de funcionar como tal. Mais do que isso, a Junta de Representantes da província haveria de

\footnotetext{
${ }^{26}$ Utilizamos o texto publicado em: REGISTRO Oficial de la Provincia de Santa Fe. 1815 al año 1817. Tomo I. Santa Fe, 1888, p. 37. Também pode ser encontrado em: CERVERA. Manuel M. Historia de la ciudad y provincia de Santa Fe, 1573-1853. Tomo II. Santa Fe: La Unión de Ramón Ibáñey, 1907. Apéndices, p. 24 et seq.
} 


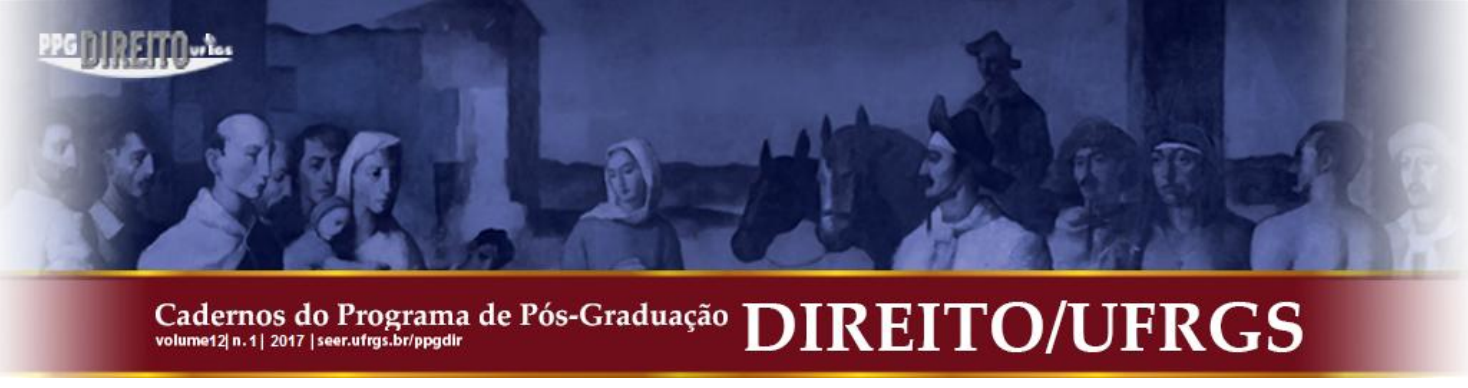

funcionar com continuidade, em que pese a apontada limitação do Estatuto ${ }^{27}$. As razões pelas quais se pode explicar essa conjunção de uma base legal constitucional a um poder unipessoal sem contrapesos e um âmbito de legalidade civil são menos complexas do que parecem. Elas remetem à coexistência de grupos civis partidários da forte tendência constitucionalista consubstanciada na revolução da independência e na emergência de um poder de fato que necessita do respaldo desses grupos. Juan Francisco Seguí, destacado porta-voz da elite de Santa Fe, expressou-o de forma não muito clara, mas bastante similar à de Pedro Ferré, em Corrientes, ${ }^{28}$ quando, a 15 de julho de 1819 , um grupo de vizinhos, opostos à continuidade do então governador Mariano Vera, levou-o ao Cabildo para persuadir o povo reunido na praça acerca da necessidade de fundar constitucionalmente a legalidade da província antes de eleger seu governador. Como narra uma memória de época:

Então, Maciel e demais acompanhantes trouxeram o doutor Juan Francisco Seguí, que, nos corredores do Cabildo, pronunciou um discurso no qual provou que não havia bom governo sem ter constituição a observar, e se o Cabildo queria que a província fosse bem governada, devia mandar fazer a constituição; e depois nomearse-ia o Governador, que juraria governar segundo ela. ${ }^{29}$

Na ocasião, o Cabildo anulou a reeleição de Vera e reassumiu o mando da província. Três dias depois, o Cabildo convocava o estabelecimento da Constituição provisória. Porém, a 23 de julho, Estanislao López apareceu na cidade acompanhado de suas tropas e se proclamou governador, iniciando um longo governo que terminaria com sua morte em junho de 1838.

No entanto, López estava preocupado com a ilegitimidade de seu acesso ao Governo [Gobernación]: “Chamado pelo bem público [salud pública], encarreguei-me de um mando que não veio a minhas mãos pela voz expressa do povo soberano", afirma em 18 de junho de

\footnotetext{
${ }^{27}$ TEDESCHI DE BRUNET, Sonia. Los últimos años de una institución colonial: el Cabildo de Santa Fe y su relación con otros espacios político-institucionales entre 1819 y 1832. Revista de la Junta Provincial de Estudios Históricos de Santa Fe, n. LIX, 1993, p. 3 et seq.

${ }^{28}$ Trata-se de oposição do líder correntino, por ocasião do regate da autonomia da província - então parte da "República de Entre Ríos", constituída pelo desaparecido caudilho Francisco Ramírez -, à eleição de um governador militar, e de sua proposta de iniciar um processo institucional sobre bases constitucionais, dado que, alegava perante os outros líderes do movimento, “(...) se fizemos a revolução para dar vida a nossa pátria, devíamos empenhar-nos para que, desde o momento de havê-lo conseguido, aparecesse com a dignidade de um estado livre e independente (...)". FERRÉ, Pedro. Memoria del brigadier general Pedro Ferré: octubre de 1821 a diciembre de 1842. Buenos Aires: Coni, 1921, p. 18.

${ }^{29}$ IRIONDO, Urbano. Apuntes. apud CERVERA. Manuel M. op. cit., Tomo II, p. 485.
} 


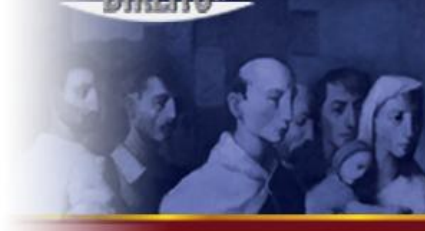

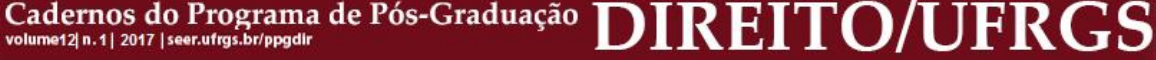

1818 , ao dispor a eleição de governador proprietário [gobernador propietario $]^{30}$. De maneira que, um ano após tomar o poder, ditava o Estatuto constitucional, o qual, segundo o historiador provincial Cervera, foi redigido pelo mesmo López, sem que possamos estabelecer o grau de coincidência entre esse texto e aquele concebido por Seguí e os seus.

Em Corrientes, um dos cimentos da formação do Estado foi o Regulamento Provisório Constitucional, de dezembro de 1821, reformado em setembro de 1824 . A reforma é devida à pressão da campanha para estar representada no Poder Legislativo ${ }^{31}$, pois, segundo o Regulamento de 1821, o Congresso Geral da província entrava em recesso depois da eleição do governador e era substituído em suas funções pelo Cabildo da cidade de Corrientes. A reforma de 1824 suprime o Cabildo e cria uma comissão permanente, composta por cinco legisladores para cumprir aquelas funções. Porém, esta não foi a única reforma significativa. Agrega-se também a extensão da cidadania a todo "aquele que haja nascido nas Américas antes denominadas de Espanholas"32, que o Regulamento de 1821 havia reservado aos naturais, e algumas expressões do texto ou de seu breve preâmbulo, tais como as do parágrafo que transcrevemos na continuação, no qual se destaca a afirmação da soberania e a denominação de nacional atribuída ao Congresso permanente: "O Exmo. Congresso da Província, usando da Soberania ordinária e extraordinária de que se investe, em razão de haver sancionado ser necessária uma Representação Nacional, composta por cinco indivíduos na capital da Província, que permaneça com todo o poder e faculdades do congresso geral $(\ldots))^{, 33}$.

Outra modificação significativa é a supressão de uma reserva efetuada no Regulamento, art. $3^{\circ}$ da Seção 3, sobre o Poder Legislativo, o qual, segundo o texto de 1821,

\footnotetext{
${ }^{30}$ CERVERA. Manuel M. op. cit., Tomo II, p. 486.

${ }^{31}$ GÓMEZ, Hernán F. Historia de la Provincia de Corrientes: desde el tratado del Cuadrilátero a Pago Largo. Corrientes: Impr. del Estado, 1929, p. 33. Em outra obra, o mesmo autor sustenta que, ao suprimir-se o Cabildo de Corrientes, em 1824, suprimiu-se a primazia dessa cidade dentro da província (GÓMEZ, Hernán F. Bases del Derecho Público correntino. Corrientes: Impr. del Estado, 1915, p. 70).

${ }^{32}$ LEY Constitucional, sancionada por el Congreso para el gobierno de la Provincia de Corrientes. Seção II, Art. 11, R.O.P.C., I, p. 246.

${ }^{33}$ LEY Constitucional, sancionada por el Congreso para el gobierno de la Provincia de Corrientes. Seção II, Art. 11, R.O.P.C., I, p. 245. O art. 1 da Seção 5, que criava esse Congresso permanente, expressa o seguinte: "Não sendo possível que os deputados do Congresso Geral sigam no exercício do Poder Legislativo por todo o tempo designado aos governadores, nem que o congresso geral se renove em períodos mais curtos pela escassez de sujeitos idôneos, o congresso geral, realizada e publicada a eleição do novo governador, empossado o eleito, e depois de haver nomeado o juiz de residência [juez de residencia], restará concentrado em cinco deputados, e esses formarão o congresso permanente" (LEY Constitucional, sancionada por el Congreso para el gobierno de la Provincia de Corrientes. Seção II, Art. 11, R.O.P.C., I, p. 250).
} 
devia exercer suas atribuições sem prejuízo de “(...) tudo aquilo que haja ou possa corresponder ao corpo ou estado geral da federação nacional"34.

\section{AS REFERÊNCIAS A UM POSSÍVEL ESTADO PLATINO NAS CONSTITUIÇÕES PROVINCIAIS}

A Constituição de Corrientes de 1824 não contém alusão alguma a um possível governo supraprovincial, e em nenhum caso condiciona o exercício da soberania pelo Congresso ou pelo Executivo - como no relativo à guerra, comércio exterior e outros assuntos - a essa possível autoridade confederativa. Da mesma forma, as Constituições de San Juan (1825), San Luis (1832) e Santiago del Estero (1831) carecem de referência a um possível Estado supraprovincial.

Porém, frente a esses casos, existem outras Constituições provinciais que, ao contrário, fazem alusão seja a um Estado, seja a uma nação rio-platense. Assim, a "Constituição da República de Tucumán”, sancionada em 18 de setembro de 1820, proclama a soberania independência provincial subordinada às resoluções do "Congresso geral da Nação", e estabelece que o Governador jurará pela Constituição e independência da província, sob a forma de governo prescrita pela Nação ${ }^{35}$.

Da mesma maneira, a Constituição da província de Catamarca (1823) invoca uma autoridade superior à provincial. Isso, contudo, ao mesmo tempo que, por um lado, a independência da província possui uma presença geral implícita no uso das atribuições estatais contidas no texto ${ }^{36}$, e, por outro, quanto à soberania, afirma-se que a província "deve levar a cabo essas prerrogativas soberanamente, mesmo depois de instalado o congresso geral, de modo tal que essa atribuição não se choque com os direitos nacionais" ${ }^{37}$.

\footnotetext{
${ }^{34}$ LEY Constitucional, sancionada por el Congreso para el gobierno de la Provincia de Corrientes. Seção II, Art. 11, R.O.P.C., I, p. 243.

${ }^{35}$ Sec. V, Cap. I, art. 2; Sec. III, Cap. I, art. 4. Para o texto desta Constituição, ver: SOSA, Ismael. Historia constitucional del Tucumán. Tucumán: Universidad Nacional de Tucumán - Facultad de Derecho y Ciencias Sociales, 1945.

${ }^{36}$ Começando pela de exercer o direito de considerar-se independente e dar-se instituições próprias, sem autoridade superior à qual se submeter, assim como o de estabelecer penas, que podem chegar à de "expatriação" e morte, aos que se constituem em "inimigo da província" por atentar contra o regulamento constitucional (REGLAMENTO constitucional para la nueva provincia de Catamarca, dado por su asamblea de 11 de julio de 1823. In: RAMOS, Juan P. op. cit., Tomo I, p. 221 e 232, art. 40, e art. 7 das "Providencias varias").

${ }^{37}$ REGLAMENTO constitucional para la nueva provincia de Catamarca, dado por su asamblea de 11 de julio de 1823. In: RAMOS, Juan P. op. cit., Tomo I, p. 219, art. 26.
} 


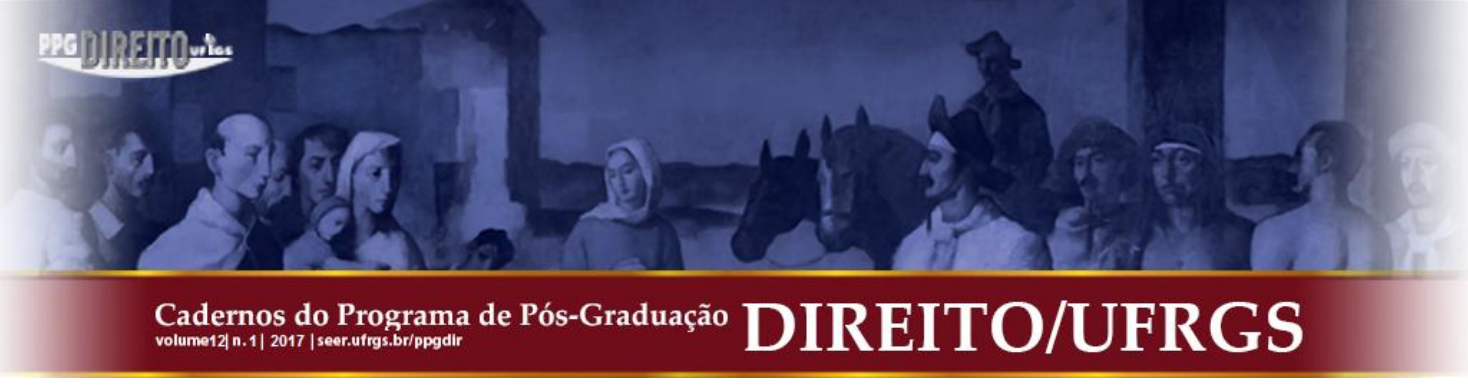

Sendo assim, ao estabelecer como objeto da assembleia provincial a regulação do comércio interior e exterior da província, e de seus sistemas monetário e de pesos e medidas, formula a exceção "salvo os direitos da nação"38.

De maneira que o trânsito de um Estado provincial soberano e independente a outro platino maior é pressuposto como produto de uma livre e soberana decisão desses Estados provinciais, e não de uma necessidade derivada de uma identidade nacional rio-platense ou, como se diria mais tarde, de uma "nacionalidade" desse caráter. Isso também é perceptível com clareza em outra característica dos textos comentados: que tanto na definição da cidadania quanto no juramento do governador, as únicas instâncias aludidas a respeito do que seria um sentimento de identidade são a província e a América.

Muito mais débil é a marca dos projetos estatais platinos no "Regulamento Provisional para os Povos Unidos de Cuyo", de 1821, regulamento que não chegou a ter vigência. Somente no terceiro ponto do preâmbulo se inclui um protesto formal pela participação em qualquer iniciativa nesse sentido: "Os Povos unidos de Cuyo declaram concorrer, a qualquer tempo, à reunião de um congresso Geral das que se denominaram [províncias] de SudAmérica, para estabelecer um Governo uniforme, que assegure sua união e Liberdade" 39 .

O restante não contém nenhuma outra referência similar e, ao contrário, mostra a presença de uma identidade americana no juramento dos Deputados do Poder Legislativo, os quais deviam jurar "a sustentação da Independência da América" ${ }^{40}$. Por outro lado, no relativo a comércio exterior, guerra e outras atividades, exerce a independência e soberania estatal da "união", "província" ou "Povos unidos" de Cuyo - distintas denominações que se sucedem no documento.

\section{AS INICIATIVAS CONSTITUCIONAIS PLATINAS E SEU REFLEXO NAS CONSTITUIÇÕES PROVINCIAIS}

Junto a esses casos, de nenhuma ou fraca emergência de uma tendência a integrar-se em um Estado superior ao provincial, as Constituições de Córdoba (1821), Salta (1821) e

\footnotetext{
${ }^{38}$ REGLAMENTO constitucional para la nueva provincia de Catamarca, dado por su asamblea de 11 de julio de 1823. In: RAMOS, Juan P. op. cit., Tomo I, p. 223, art. 62.

${ }^{39}$ REGLAMENTO provisional de Gobierno para los Pueblos de Cuyo, 1821. In: RAVIGNANI, Emilio (Org.). op. cit., 1937, Tomo VI, Segunda Parte, p. 1129.

${ }^{40}$ REGLAMENTO provisional de Gobierno para los Pueblos de Cuyo, 1821. In: RAVIGNANI, Emilio (Org.). op. cit., 1937, Tomo VI, Segunda Parte, p. 1130 e 113, arts. 14 e 40.
} 
Entre Ríos (1823) mostram, por outro lado, uma forte presença dela. Nesses documentos influi a iminência das assembleias constituintes então projetadas ${ }^{41}$. Ademais, duas delas refletem situações nas quais os governos provinciais estavam diretamente comprometidos com esses projetos de imediata reunião de congressos constituintes rio-platenses. A província de Córdoba em 1821 impulsionava um projeto de congresso constituinte sob sua liderança, que seria prontamente bloqueado por Buenos Aires. A de Entre Ríos, porque, sob o governo do portenho Lucio Mansilla, constituía-se uma aliada incondicional de Buenos Aires, província que nesse ano de 1823 já havia logrado o concurso das demais para a reunião que seria o congresso constituinte de 1824-26.

O Regulamento Provisório da província de Córdoba, de janeiro de $1821^{42}$, proclama a soberania e independência da província em seu segundo artigo: “A província de Córdoba é livre e independente: nela reside essencialmente a soberania e lhe compete o direito de estabelecer suas leis fundamentais por constituições fixas [fijas], como também por regulamentos provisórios (...)”.

Porém, acresce: “(...) enquanto não prejudique os direitos particulares das demais províncias e os gerais da confederação". Além disso, o último artigo da seção eleitoral alude à eleição de "representantes para o congresso geral dos estados",43.

$\mathrm{Na}$ seção sobre o Poder Legislativo, distingue as faculdades do congresso provincial para estabelecer a Constituição que rege a província da do "congresso geral dos estados" para examinar se a Constituição "se opõe ou não à autoridade da confederação". Assim como declara a competência do congresso provincial para ordenar a guerra se a província for invadida, enquanto que, fora desse caso, considera decretar a guerra e a paz competência do Congresso geral dos estados ${ }^{44}$. O restante dos artigos, assim como outros das outras seções, repete, com critério semelhante, a distinção de competências, incluído o relativo a direitos de importação e exportação (notar que aqui se dá, por sua vez, a admissão da soberania da

\footnotetext{
${ }^{41}$ Veja-se uma resenha da evolução das negociações para um congresso constituinte rio-platense entre 1820 e 1824, em: RAVIGNANI, Emilio. "El Congreso nacional de 1823-1827, La Convención nacional de 1824-1829, Inconstitución y régimen de pactos". Historia de la Nación Argentina. 3. ed. v. VII, Primera Sección. Buenos Aires: Academia Nacional de la Historia, [s.d.], p. 10 et seq.

${ }^{42}$ REGLAMENTO provisorio de la provincia de Córdoba para el régimen de las autoridades de ella, expedido el 30 de enero de 1821. In: RAMOS, Juan P. op. cit., Tomo I, p. 153 et seq.

${ }^{43}$ REGLAMENTO provisorio de la provincia de Córdoba para el régimen de las autoridades de ella, expedido el 30 de enero de 1821. In: RAMOS, Juan P. op. cit. Tomo I. Sec. Ia, Cap. I, art. 2, p. 153; Sec. IV, Cap. X, art. 12, p. 161.

${ }^{44}$ REGLAMENTO provisorio de la provincia de Córdoba para el régimen de las autoridades de ella, expedido el 30 de enero de 1821. In: RAMOS, Juan P. op. cit. Tomo I. Sec. VI, Cap. XIII, arts. 1 e 2, p. 163.
} 


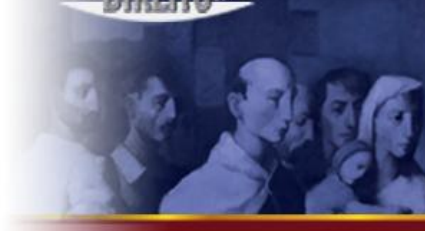

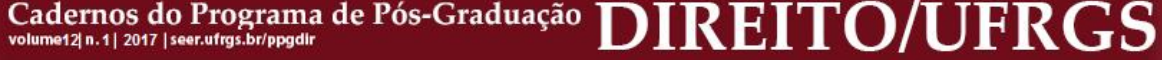

província para estabelecê-los e da faculdade da autoridade confederativa para decidir se é compatível com os compromissos interprovinciais). Quiçá o mais explícito seja o último dos relativos ao Poder Executivo: “As atribuições essenciais do poder executivo da confederação e as que o voto das províncias reunidas em congresso tiver por bem refundir no governo geral dos Estados serão limites ao poder executivo desse Estado"45.

Contudo, esta referência a uma possível política superior à província tampouco reflete uma consciência de nacionalidade. Num parágrafo, nisso similar aos de outras Constituições como as de Santa Fe e Catamarca, o texto constitucional de Córdoba tão somente mostra uma identidade distinta da provincial, a sul-americana, quando obriga os espanhóis e demais estrangeiros a jurar defender “(...) a independência de sur América (...)"46.

O mesmo ocorre em um notável parágrafo que estabelece que estão em vigência todas as leis e demais disposições do "antigo governo espanhol" que não estejam em oposição direta ou indireta à “(...) liberdade e independência de Sud América, nem a este regulamento e demais disposições que não sejam contrárias a ele definidas pelo governo geral das províncias desde 25 de Maio de 1810״47.

Essa Constituição de Córdoba de 1821, como já apontamos, reflete a política do governo de Bustos, que impulsionava decididamente um congresso de todas províncias rioplatenses a reunir-se em Córdoba. Ela mostra, ademais, que desse congresso se esperava uma confederação. O fracasso do projeto de Bustos, fundamentalmente em decorrência da oposição da província de Buenos Aires, a qual buscava, e conseguiria, reunir um congresso unitário em sua capital, tiraria a validade dessas cláusulas que limitam o exercício da soberania em função do estabelecimento do possível governo confederativo, cláusulas que, como veremos, estarão ausentes da nova Constituição de Córdoba de 1847.

A primeira constituição para a província de Salta - que então incluía Jujuy, separada recém em 1834 -, data de 2 de agosto de $1821^{48}$. Em realidade, não é mais do que uma

\footnotetext{
${ }^{45}$ REGLAMENTO provisorio de la provincia de Córdoba para el régimen de las autoridades de ella, expedido el 30 de enero de 1821. In: RAMOS, Juan P. op. cit. Tomo I. Sec. VI, Cap. XVI, art. 17.

${ }^{46}$ REGLAMENTO provisorio de la provincia de Córdoba para el régimen de las autoridades de ella, expedido el 30 de enero de 1821. In: RAMOS, Juan P. op. cit. Tomo I. Sec. III, Cap. VI, art. 9.

${ }^{47}$ REGLAMENTO provisorio de la provincia de Córdoba para el régimen de las autoridades de ella, expedido el 30 de enero de 1821. In: RAMOS, Juan P. op. cit. Tomo I. Sec.VI, Cap. XII, art. 3, p. 162. Nesse parágrafo há duas coisas notáveis: uma, a já indicada; outra, que não reconhece a legislação do governo geral das províncias que contradiga a Constituição provincial.

48 Texto incluído no Apêndice ao Tomo 2 de: RAVIGNANI, Emilio. Historia Constitucional de la República Argentina. Tomo II. Buenos Aires: Peuser, 1927, p. 376 et seq.
} 


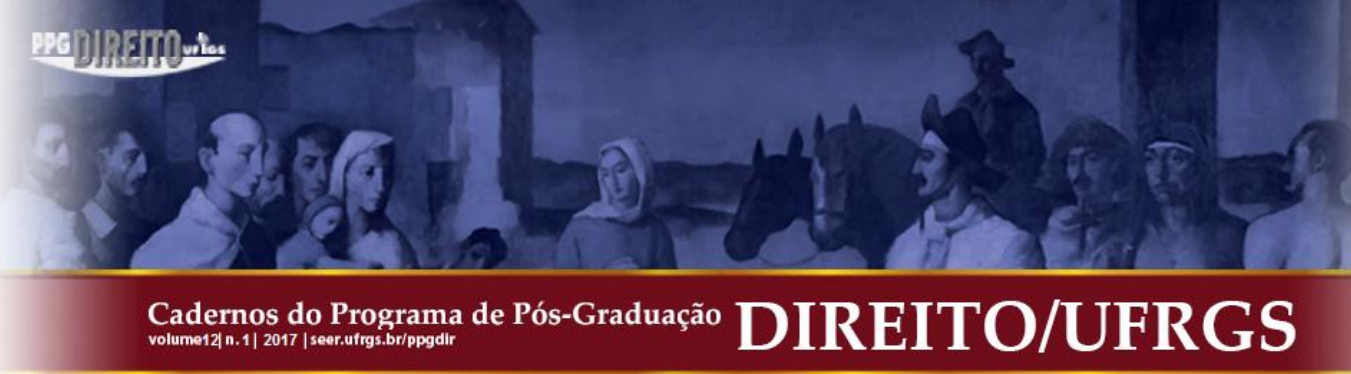

listagem de artigos que possuem forte tom provisional, incluída em uma ata sem título algum (como existem em outros casos provinciais, tais como "Estatuto provisional" ou "Regulamento provisional"). A ata expressa que se trata de regras para a boa orientação do governador que os deputados se preparavam para eleger. Em virtude da forte invocação do Congresso Nacional, também pertence aos textos elaborados por províncias - ou partidos dentro delas - comprometidas com algum projeto de Congresso constituinte em elaboração: " $1{ }^{\circ}$ Que todos os atos que procedem, regras que prescrevem, e disposições que, segundo elas, se tomem, fiquem inteiramente sujeitas à aprovação, reforma e variações que o Congresso Nacional quiser efetuar".

Pouco mais adiante, o segundo inciso do artigo $3^{\circ}$ remete ao Regulamento Provisório de 1817 e à Constituição de 1819 "em tudo o que forem adaptáveis ao regime desta província".

O juramento do governador incluía "defender a independência da Nação e sustentar os direitos da província contra toda agressão inimiga". E, inclusive, num parágrafo da ata posterior à transcrição do articulado, lê-se o seguinte: "Estabelecidas as declarações anteriores e declarando novamente os S. S. Representantes que elas só regeriam até o Congresso Nacional ditar outras em seu lugar (...) ${ }^{» 49}$. Em que pese tudo isso, o regulamento constitucional não deixa de conceder à província o exercício de direitos soberanos sobre comércio exterior, moeda, pesos e medidas, guerra e patronato.

Quanto a Entre Ríos, é necessário recordar que esta província foi, desde a norte do caudilho Francisco Ramírez, uma dependência política da de Buenos Aires. Sua constituição reflete nos dois primeiros artigos a plena adesão da província ao congresso constituinte impulsionado por Buenos Aires. O primeiro declara que a província se constitui em "Estado e Governo Representativo independente" até a decisão que o congresso geral de todas as províncias platinas venha a tomar sobre a forma de governo. E o segundo artigo expressa que a província de Entre Ríos “(...) é uma parte integrante das Províncias Unidas do Rio da Prata, e forma com todas uma só Nação, que se reconhecerá sob aqueles termos, ou outros que o Congresso Geral acorde, a cujas deliberações sujeita-se desde agora (...) ${ }^{, 50}$.

\footnotetext{
${ }^{49}$ RAVIGNANI, Emilio. op. cit., 1927, p. 381.

50 "Estatuto provisorio constitucional de la Provincia de Entre Ríos", de 1823, disponível em: RECOPILACIÓN de Leyes, Decretos y Acuerdos de la Provincia de Entre Ríos, desde 1821 a 1873. Tomo I - 1821 a 1824, p. 138 et seq.

Cadernos do Programa de Pós-Graduação em Direito PPGDir./UFRGS | Edição Digital | Porto Alegre | Volume XII| Número 1 | 2017 | P. 73 - 114
} 


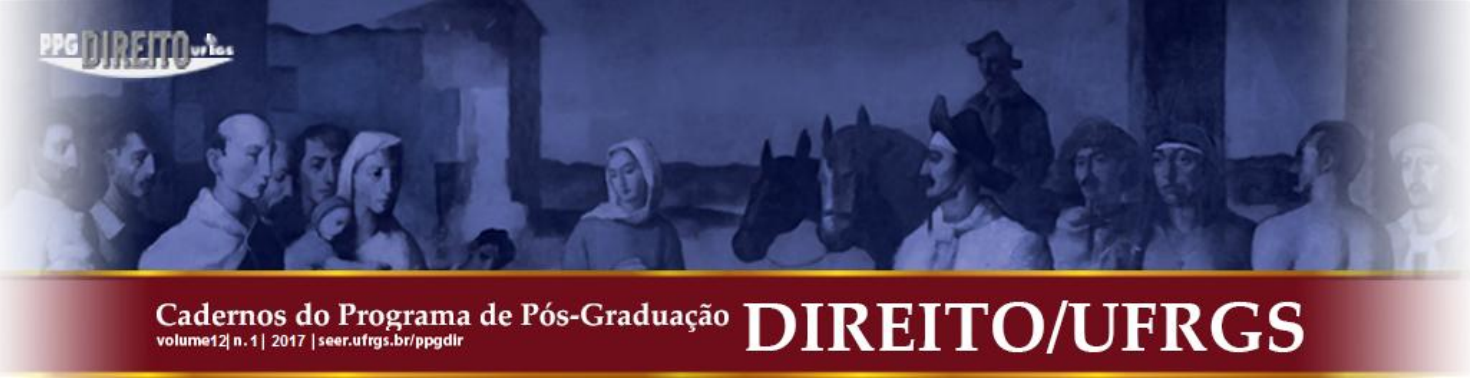

Se a declaração constitucional de independência e soberania estatal é um dado substancial entre os que apontam a emergência do Estado provincial autônomo, outros - não menos importantes nesse plano - constituem-se na definição das faculdades constitucionais para o exercício da soberania estatal em diversos âmbitos da organização social. Os principais campos em que as Constituições afirmam expressamente o exercício da soberania do Estado provincial são os de organização jurídico-política, finanças públicas, comércio exterior, defesa, relações interprovinciais, moeda [amonedación], regulação de pesos e medidas, exercício do patronato e organização do ensino. De outra parte, é conveniente advertir que da ausência de menção expressão a alguns deles não se segue em todos os casos que a província haja limitado o exercício de sua soberania ${ }^{51}$.

Como observamos mais acima, o conjunto dos textos constitucionais platinos mostra, nos anos iniciais dos novos Estados provinciais (1819 a 1824), uma expressão antecipada de desenvolvimento estatal independente unida à incidência dos projetos de novos congressos constituintes rio-platenses (o de Córdoba, abortado, e o de Buenos Aires, realizado em 18241826), incidência expressa em invocações ao mesmo [um desses Congressos], como um possível limite à afirmação soberana do Estado provincial.

Por outro lado, no caso de províncias que se dão novas Constituições nos anos posteriores ao Pacto Federal de 31, esses textos exibem, a um só tempo, menor ênfase na alusão ao laço confederativo e maior e mais detalhada expressão do exercício da soberania em campos como os da política econômica, defesa e também em aspectos das relações exteriores, como os implícitos no direito do patronato. A inferência é que o processo de afirmação da soberania e independência estatal foi aumentando, mesmo paralelamente ao fortalecimento da influência política de Buenos Aires em muitas delas. Vínculo político intergovernamental que não foi óbice para esse fortalecimento da independência estatal das chamadas províncias do Rio da Prata, e que tem, na versão confederativa do federalismo, versão então exclusiva na região, um dado que a confirma, conforme exporemos mais abaixo.

\footnotetext{
${ }^{51}$ Sobre este assunto, e o que segue, conferir nosso trabalho: CHIARAMONTE, José Carlos. El federalismo argentino en la primera mitad del siglo XIX. In: CARMAGNANI, Marcello (Coord.). Federalismos latinoamericanos: México/Brasil/Argentina. México: El Colegio de México; F.C.E., 1993.
} 


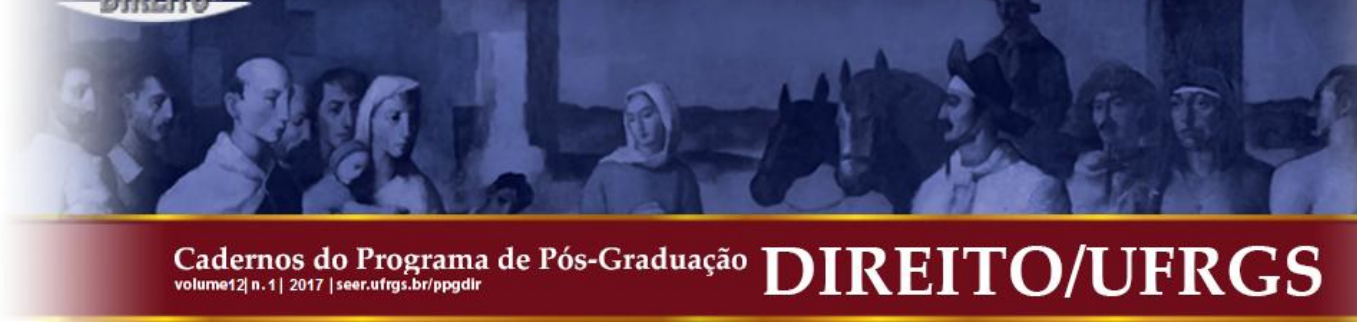

\section{O FRACASSO CONSTITUCIONAL DE 1826 E O AVANÇO DA SOBERANIA E INDEPENDÊNCIA PROVINCIAIS}

Os textos constitucionais provinciais que nos mostram, nos anos imediatamente posteriores ao rechaço à Constituição de 1819 , essa diversificada atitude em relação aos projetos de organização de um Estado platino, desde uma eloquente ausência de interesse por eles a uma forte presença de tais projetos, em nenhum caso, todavia, manifestam qualquer consciência de nacionalidade platina ou argentina. De qualquer modo, é patente que, no que tange ao governo ou Estado confederativo a constituir-se - no caso dos textos constitucionais que o mencionam - é pensado em termos rio-platenses; já as manifestações de sentimentos de identidade que vão mais além do âmbito provincial, são de natureza americana. Significa dizer que, quanto a sentimentos de identidade coletiva, os constituintes das províncias platinas se concebem a si mesmos como americanos, ainda não como argentinos, enquanto que, em termos de organização política, no caso daquelas que remetem a uma possível união, sua delimitação é, sim, argentina ou platina.

Esta tendência se fortaleceu, paralela ao fortalecimento das independências e soberanias dos Estados provinciais, logo depois da fracassada tentativa de impor uma solução de governo centralizado, então chamado de unitário, por parte dos homens de Buenos Aires, em 1826. E teve sua expressão máxima nos acordos que se converteram no Pacto Federal de 1831.

A partir de então, consolidar-se-á o pertencimento a uma República Argentina organizada confederativamente. Porém, na medida em que a Confederação pactuada em 1831 não avançava no caminho de uma maior união constitucional - caminho vetado por conta da oposição de Buenos Aires em manter a Comissão Representativa que havia decidido o Pacto Federal e a convocar um congresso constituinte também previsto pelo Pacto -, as novas Constituições provinciais refletiriam o exercício de atribuições equivalentes às nacionais nestas províncias-Estados.

Um claro exemplo disso é a Constituição de Córdoba de 1849, que mantém grande parte do texto de 1821 mas que, naquilo que o modifica, acentua o exercício da soberania estatal. Esta nova Constituição de Córdoba continua invocando a autoridade maior da República Argentina, porém, com assiduidade muito menor do que a de 1821. Desapareceram, por exemplo, as contínuas referências às atribuições do "congresso geral dos 


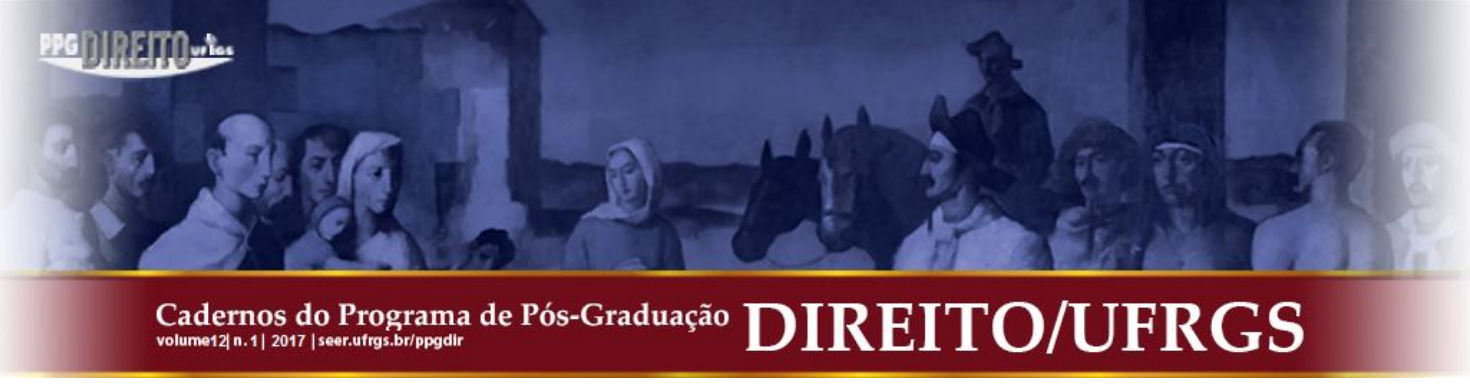

estados", com que o texto de 1821 fixava os limites ao exercício das da província ${ }^{52}$. À diferença do de 1821, no qual se percebe a suposta iminência de uma organização estatal supraprovincial, o texto de 1847 é reflexo nítido de um Estado soberano, unido aos outros platinos pelos tênues laços confederativos pactuados em 1831. Assim, as atribuições estatais são mais amplas do que no texto de 1821, especialmente em virtude dos direitos de estabelecer impostos de importação e exportação, de dispor da moeda [amonedación] provincial e de regular o sistema de pesos e medidas, enquanto mantém igualmente o direito de patronato em questões eclesiásticas - Capítulo XV, art. 10. E é especialmente significativa a substituição do Capítulo XXVI do texto de 1821 ("Das milícias nacionais") - no qual se afirmava o direito da província de organizá-las enquanto o "congresso geral dos estados" não o fizesse - por um capítulo - o XVIII ("Milícias da província”) - que não contém nenhuma alusão a forças nacionais.

De outra parte, segue ausente uma nacionalidade argentina que vá mais além da união confederativa nas invocações das "causas" a defender. O juramento do governador inclui este parágrafo: “(...) que defenderá a liberdade e independência americana contra todo poder estrangeiro e a santa causa nacional da federação, que sustentará a integridade do território da província e seus direitos contra toda agressão (...)",53.

A nova constituição de Santa Fe já havia mostrado tendência similar em 1841, com uma forte afirmação da soberania, independência e liberdade da província, que se bem não tem a contundência do texto de Córdoba, é indicadora de uma orientação similar: "A província de Santa Fe de la Veracruz se declara e se constitui em um formal Estado e governo representativo e independente. Sua soberania reside essencialmente no conjunto de gentes que a habitam e é o que se chama Estado".

\footnotetext{
52 Traço especialmente notável no Cap. XIII ("Atribuições do Congresso") da Seção VI da Constituição de 1821, no qual a metade de seus 14 artigos incluem a fórmula citada, enquanto que, na mesma Seção e Capítulo, a Constituição de 1849 carece de referências a alguma autoridade superior. É útil comparar, por exemplo, os artigos de ambas as Constituições referentes à faculdade de regular o comércio exterior da província: "Corresponde ao congresso da província, com anuência e consentimento do Congresso geral dos estados, estabelecer direitos de importação e exportação ao comércio interior e ao estrangeiro, sendo um dever das leis gerais da união procurar uniformizá-lo na liberdade de toda sorte de entraves funestos à mútua prosperidade das províncias federais" (Constituição de 1821, Sec. VI, Cap. XIII, art. $5^{\circ}$ ). O texto do artigo sobre comércio exterior da Constituição de 1849 (art. $4^{\circ}$ ) é o seguinte: "Corresponde ao Poder Legislativo estabelecer direitos de importação e exportação";

${ }^{53}$ Cap. XV, art. 13.
} 


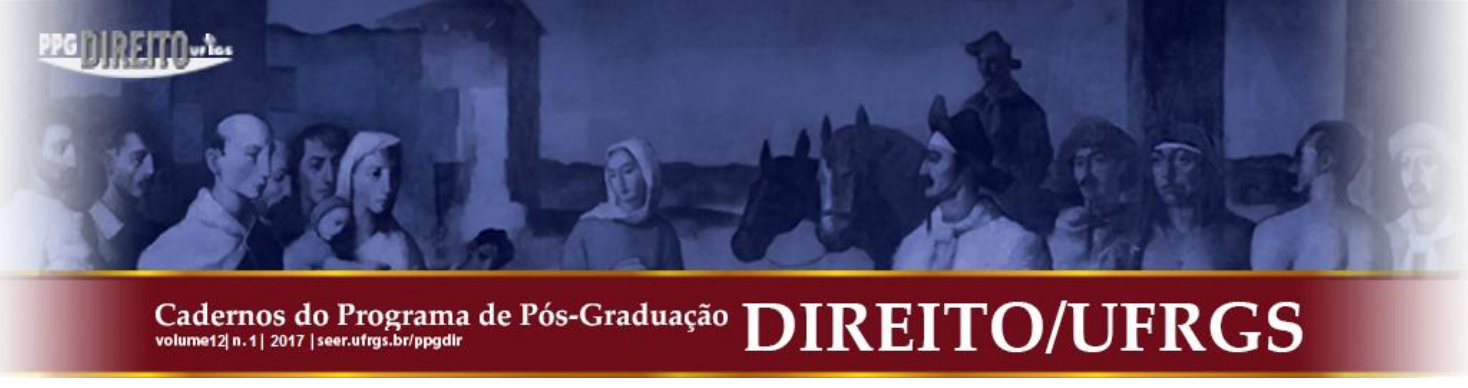

A esta rotunda afirmação de sua soberania estatal, segui um breve segundo artigo, no qual se proclamava a integração à Confederação argentina: "Ela pertence à República Argentina e é uma das que compõem sua confederação" $" 54$.

Congruentemente com esta menção ao seu pertencimento à Confederação argentina, invocada também no juramento do governador e na seção sobre "Deveres da província", as Seções III e VI, sobre atribuições dos poderes Legislativo e Executivo, respectivamente, carecem de qualquer restrição ao exercício dessas atribuições no referente a guerra, comércio exterior, tributação e outras esferas de atividade. Isto é, nos campos em que a soberania do Estado provincial não havia sido delegada à Confederação, como ocorria com as relações exteriores - caso em que, na falta de um órgão de governo da mesma [Confederação], eram delegadas ao governador de Buenos Aires.

Uma novidade é a menção à República Argentina no juramento do governador ao assumir o cargo: “(...) que sustentarei a liberdade e independência da República Argentina e, em particular, desta província sob o sistema federativo (...)"55. Todavia, no atinente à cidadania, continua a política de concedê-la a filhos da província e aos americanos.

É importante que advirtamos outro traço da linguagem política da época nesses textos constitucionais provinciais: a não utilização do termo "argentinos" como vocábulo correspondente a Argentina (República ou Confederação), o que sugere que a República Argentina designa a reunião das sociedades provinciais, porém, não a uma sociedade nacional amalgamada - à qual corresponda um sentimento de forte pertencimento -, qualidade essa que se percebe, sim, nas referências à pátria provincial: “[todo cidadão] deve servir à pátria quando ela o exija, sacrificando até sua vida se necessário, e cujo heroico exercício constitui o verdadeiro patriotismo" ${ }^{, 56}$.

\section{FEDERAÇÃO OU CONFEDERAÇÃO? O MITO DAS ORIGENS E A NOÇÃO DE FEDERALISMO}

Se atentamos às dificuldades concernentes à interpretação do uso do conceito de nação no período imediatamente posterior à independência, poderemos reexaminar com melhores

\footnotetext{
${ }^{54}$ Sec. I, arts. 1 e 2.

55 Sec. V, art. 29.

${ }^{56}$ Sec. X, "Deveres de todo cidadão", art. 82.
} 


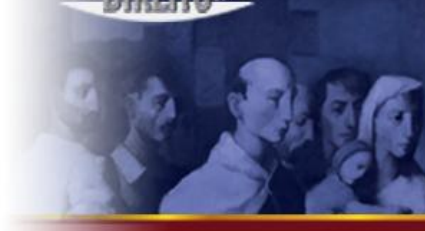

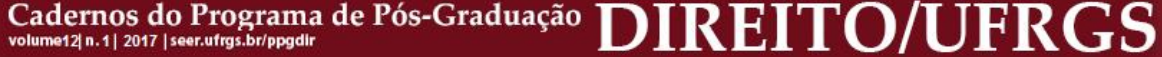

perspectivas a questão do federalismo, enquanto problema substantivo dessa discussão. Porque, para que o processo de organização política dos povos rio-platenses possa ser melhor compreendido, é necessário despojar-se da perspectiva anacrônica que impulsionou o mito romântico do princípio das nacionalidades. Os líderes políticos platinos das duas primeiras décadas posteriores a 1810 utilizavam uma linguagem na qual estavam ausentes os pressupostos românticos implícitos ao conceito de nacionalidade e se regiam pela lógica racionalista do contratualismo herdado do século XVIII. Consideravam que a união política Estado -, que pretendiam organizar com o nome de nação, não era fruto de um imperativo do passado, mas de negociações regidas pelo princípio da conveniência mútua, com concessões recíprocas e formas contratuais ${ }^{57}$.

Recordemos, também neste ponto, a necessidade de superar alguns lugares comuns de nossa historiografia, a qual habitualmente considerou as províncias que se formaram no Rio da Prata na sequência da independência como partes de um Estado nacional platino. Mesmo nos períodos em que esse Estado não existia, como nos dias imediatamente posteriores à independência, ou em boa parte dos lapsos transcorridos entre cada um dos intentos fracassados de organizá-lo constitucionalmente, tampouco deixou de considerá-las como partes desse possível Estado, do qual só por acidente se encontrariam privadas.

O que segue não compartilha esse ponto de vista e, em seu lugar, considerará, segundo o já exposto em diversos momentos deste trabalho, que logo da independência a construção de novos Estados hispano-americanos era um assunto ainda indefinido e que, portanto, a natureza política das chamadas províncias rio-platenses também foi algo aberto a diversas possibilidades. Uma delas, a de converterem-se em Estados independente. Outra, a de integrarem-se em um Estado maior que as englobasse. E, neste último caso, também com distintas possibilidades, dado que grande parte do que tradicionalmente costumamos considerar como tendências federais consistia, na realidade, em políticas de união confederativa, quando não de simples ligas ou alianças. Políticas com as quais as chamadas províncias atuavam na qualidade de Estados independentes e soberanos. E é, insistamos, o equívoco persistente que se arraiga o de chamar federais aos caudilhos e outras figuras políticas da época o que contribui para nos impedir de uma melhor análise da questão.

\footnotetext{
${ }^{57}$ De outra parte, a aplicação do princípio das nacionalidades na América hispânica tinha o irritante problema de remeter a uma unidade hispano-americana e não a recortes argentinos, chilenos, venezuelanos etc. Sobre o tema, ver nosso trabalho: CHIARAMONTE, José Carlos. El mito de los orígenes en la historiografía latinoamericana. Cuadernos del Instituto Ravignani, Instituto de Historia Argentina y Americana “Dr. Emilio Ravignani”, n. 2, 1991.
} 


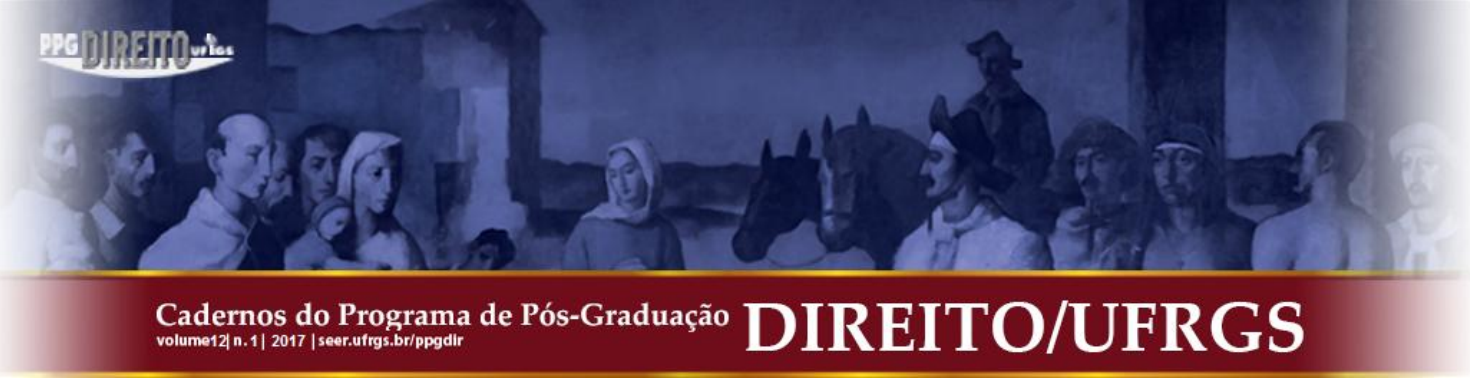

Nada mais útil, então, para esse intento que observar a história do uso do próprio vocábulo "federalismo". Pois poucos foram tão centrais à questão do Estado e da nação rioplatense, e ainda assim tão confundidos. A esse respeito, devemos assinalar que outro lugar comum de antiga data na historiografia argentina, porém que perdurou até hoje, é o que identifica, e, portanto, confunde, federalismo e confederacionismo. É dizer, trata-se do equívoco de considerar as iniciativas às vezes confederativas, outras vezes meramente pactistas, que vão desde a independência até a Constituição de 1853, como manifestações de uma mesma tendência federal, tal como a que prevaleceu na última dessas datas. E, portanto, irrupção do Estado federal em 1852-53 - Acordo de São Nicolau-Constituição - como simples continuidade das políticas opostas ao monarquismo e ao unitarismo, julgadas igualmente como federais.

O assinalado é tanto mais estranho porque não deixaram de existir, desde o começo mesmo do processo de organização estatal rio-platense, advertências sobre a necessidade de não confundir confederação e federação ${ }^{58}$. Expresso nos termos da polêmica do momento, a necessidade de não confundir, quando se invocava o exemplo dos Estados Unidos da América, os Artigos de Confederação (1781) e a Constituição federal (1787) ${ }^{59}$, assunto no qual será útil nos determos.

\section{FEDERAÇÃO, CONFEDERAÇÃO, "GOVERNO NACIONAL"}

De alguma maneira, a confusão comentada não faria outra coisa que prolongar a forma com que a literatura política anterior à experiência do constitucionalismo norte-americano

\footnotetext{
${ }^{58}$ A Gaceta, em comentário a $O$ Federalista, que combate, afirma que "a ideia da divisão de estados ou federações separadas (...) (GACETA. Artigo "sobre federaciones". 30/III/1815, p. 507). Do mesmo modo, o Congresso de 1816 conheceu os Artigos de Confederação dos Estados Unidos: cf. PADILLA, Alberto Gabriel. La Constitución de Estados Unidos como precedente argentino. Buenos Aires: Jesús Menéndez, 1921, p. 50-51. Mais tarde, Sarmiento também distinguiu com bastante propriedade a distinta natureza da Confederação norte-americana de 1781 quanto a de Estado federal de 1787, e rechaçava o termo confederação para designar o emanado da Constituição argentina de 1853 - SARMIENTO, D. F. Comentarios de la Constitución. Buenos Aires: Luz del Día, 1948, p. 55 et seq. [Primeira Edição: SARMIENTO, D. F. Comentarios de la Constitución de la Confederación Argentina. 1. ed. Santiago de Chile: Imprenta de Julio Belín y Ca., septiembre de 1853].

${ }^{59}$ Sobre as características da influência do constitucionalismo norte-americano do século XVIII, há uma extensa bibliografia, frequentemente polêmica, cujos primeiros títulos nos remetem aos dias imediatamente posteriores à sanção da Constituição de 1853. Uma síntese recente, além de outras referências que efetuaremos no curso deste capítulo, pode ser encontrada em: VANOSSI, Jorge R. Situación actual del federalismo. Buenos Aires: Depalma, 1964. Do mesmo autor, ver: VANOSSI, Jorge R. La influencia de la Constitución de los Estados Unidos de Norteamérica en la Constitución de la República Argentina. Revista Jurídica de San Isidro, dez. 1976; também: VANOSSI, Jorge R. El estado de derecho en el constitucionalismo social. 2. ed. Buenos Aires: Eudeba, 1987.
} 


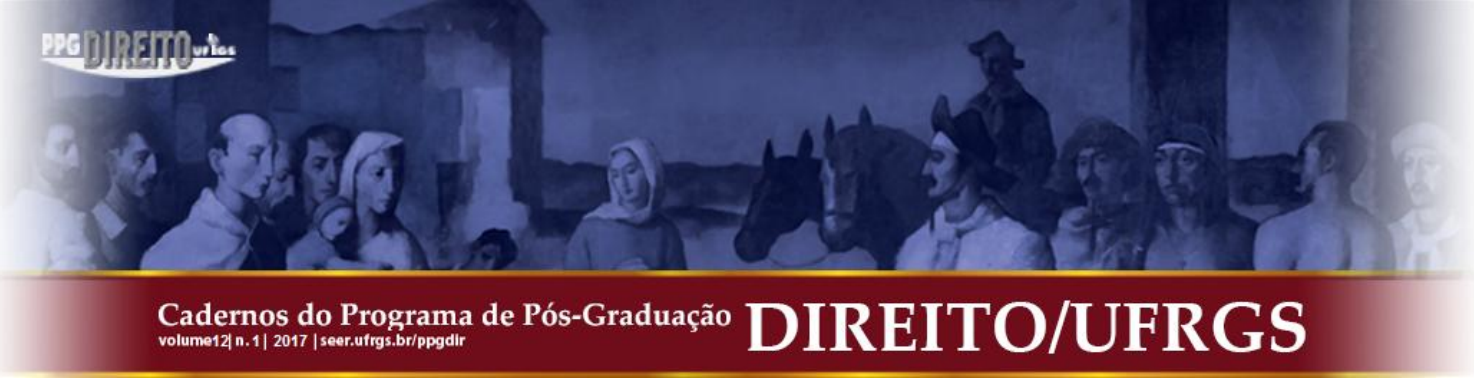

tratava o assunto. Tal, por exemplo, como o faz Montesquieu numa das mais recorridas fontes do debate constitucional daqueles tempos, seu Espírito das Leis ${ }^{60}$. Até o momento em que a Constituição da Filadélfia inaugurara essa forma inédita de resolver o dilema da concentração ou desconcentração do poder que conhecemos como federalismo norte-americano - e que dá origem à aparição de um novo sujeito de direito internacional, o Estado federal -, os tratadistas políticos conheciam uma só forma de federação, a confederação - união de Estados independentes -, e a ela se referiam com exclusividade quando abordavam o tema do federalismo.

Por isso, encontramos nos editores norte-americanos de $O$ Federalista uma distinção de termos que pode nos surpreender. Trata-se de seu uso, ao relacioná-los, em uma acepção estranha a nosso critério atual: o federal oposto ao nacional, entendendo por "federal" o confederativo, e por nacional o Estado federal que propunham seus autores. Por exemplo, ao considerar qual tipo de governo é o proposto na nova Constituição, Madison observa que, caso se considere segundo seus fundamentos, o novo sistema norte-americano seguiria sendo federal [i.e., confederativo] e não nacional [i.e., federal], dado que a aprovação da nova Constituição seria realizada não pelos cidadãos norte-americanos enquanto tais, mas como povo de cada Estado para que estes a ratifiquem. É dizer, pelo povo “(...) não como indivíduos que integram uma só nação, mas como componentes dos vários Estados, independentes entre si, aos quais respectivamente pertencem. (...) Portanto, o ato que instituirá a Constituição não será um ato nacional, mas federal",61.

A solução de compromisso do presidencialismo norte-americano, algo não previsto em doutrina alguma, com sua justaposição de uma soberania nacional e das soberanias estatais, solução empírica para o conflito político derivado da ineficácia dos Artigos de Confederação

\footnotetext{
${ }^{60}$ Utilizamos a edição espanhola (MONTESQUIEU. Del espíritu de las leyes. Madrid: Tecnos, 1985). Sobre a "república federativa" (confederação), ver a Segunda Parte, Libro IX "De las leyes en su relación con la fuerza defensiva", capítulos I a III.

${ }^{61}$ HAMILTON; MADISON; JAY. op. cit., p. 161. Madison acrescenta que o ato não será resultado da decisão da maioria do povo da União. Nem sequer da maioria dos Estados, dado que deve resultar do assentimento unânime desses. E comenta, depois de uma análise dos traços, sejam federais, sejam nacionais, do sistema proposto: "A diferença entre um governo federal e outro nacional, no que se refere à atuação do governo, considera-se que assenta em que, no primeiro, os poderes atuam sobre os corpos políticos integrantes da Confederação, em sua qualidade política; e, no segundo, sobre os cidadãos individuais que compõem a nação, considerados enquanto tais como indivíduos" (HAMILTON; MADISON; JAY. op. cit., p. 162).
} 


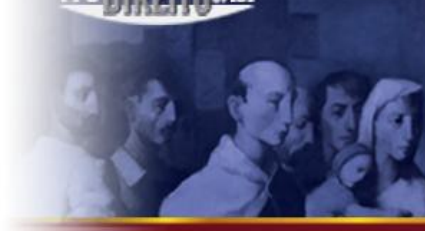

de 1781 para organizar uma nação, não correspondia ao que a doutrina política então entendia por federalismo, enquanto forma de Estado oposta à de unidade ${ }^{62}$.

Posteriormente, a partir do estudo do processo político norte-americano, será elaborada a distinção entre o conceito de federação e o de confederação, se bem que, no entanto, encontram-se sérias dificuldades para defini-los e precisar suas diferenças ${ }^{63}$. Assim, discutiu-se como definir a confederação, como distinguir suas características das do Estado federal, como deslindar a dificuldade da superposição do direito internacional e do direito interno que ela implica, como abordar a questão da soberania e da personalidade estatal, e outros problemas, todos estritamente conectados entre si. Segundo um ponto de vista suficientemente compreensivo, a confederação seria “(...) uma sociedade de Estados independentes, que possuem órgãos próprios permanentes para a realização de um fim comum"64.

Em geral, as considerações a respeito da confederação, que em última instancia não fazem outra coisa que refletir a experiência histórica conhecida - a liga aqueia, a

\footnotetext{
${ }^{62}$ Característica que Tocqueville já observava num texto em que, ao mesmo tempo que dá conta da distinção - que posteriormente se expressou no atual uso diferenciado dos termos federação e confederação -, segue, no entanto, usando o vocábulo confederação para aludir ao Estado federal surgido da Constituição da Filadélfia: "Esta Constituição, que à primeira vista alguém pode ver-se tentado a confundir com as Constituições federais que a precederam, repousa, com efeito, sobre uma teoria inteiramente nova, a qual deve-se apontar como um grande descobrimento da ciência política dos nossos dias. Em todas as confederações que precederam a confederação norteamericana de 1789, os povos que se aliavam com um fim comum consentiam em obedecer às determinaçõos de um governo federal; porém, conservavam o direito de ordenar e vigiar entre si a execução das leis da União. Os Estados da América do Norte que se uniram em 1789 não só consentiram que o governo federal lhes ditasse leis, mas também que ele mesmo as executasse" (TOCQUEVILLE, Alexis de. La democracia en América. México: F.C.E., 1957, p. 151).

${ }^{63}$ Um dado significativo para perceber a persistência da confusão da linguagem na Argentina é que Lucio V. López, em seu curso de Direito constitucional, não perceba essa diferença entre confederação e estado federal, tanto ao tratar do caso norte-americano como do argentino - LÓPEZ, Lucio V. Curso de Derecho Constitucional: Extracto de las conferencias dadas en la Universidad de Buenos Aires. v. I. Buenos Aires, 1891, p. 96 e 271 et seq. Contudo, mais notável é que, no segundo desses lugares, trate o caso argentino como confederativo, para sublinhar as faculdades dos governos provinciais emanadas da Constituição: "Os governos de província são a agrupação que constitui a verdadeira nação; seja do governo nacional, um governo de exceção, não só pela especialidade [sic: especificidade?] das matérias que lhe competem, seja porque teve por objeto sua criação arrebatar dos governos de província todas aquelas faculdades que poderiam originar conflitos se seu exercício fosse deixado aos poderes de província".

${ }^{64}$ Resumindo sua análise, o autor que transcreve esse texto, acrescenta: "A ideia consiste, portanto, em que na confederação os Estados se vinculam de modo permanente em uma organização paritária, por meio de laços internacionais, que dá lugar a uma instituição internacional que atua em nome dos Estados membros em determinadas relações, tratados, declaração de guerra e, às vezes, com fins económicos, administrativos ou políticos, com graus diversos de cristalização e eficácia prática. A notas de permanência, organização e diversidade de fins da confederação distinguem-na de outras ligas internacionais (alianças, por exemplo)". OTTOLENGHI, Giuseppe. Lezioni di Diritto Internazionale Pubblico. Anno Academico 1946-47. Torino: G. Giappichelli, p. 146 - apud VERDÚ, Pablo Lucas. Confederación. In: MASCAREÑAS, Carlos E. (Coord.). Nueva Enciclopedia Jurídica. Tomo IV. Barcelona: Francisco Seix, 1952, p. 911. Esse artigo provê um útil resumo do tema (p. 910 et seq.). Uma síntese, com uma extensa bibliografia, encontra-se também em: SPOTA, Alberto Antonio. Confederación y estado federal: Conceptos y esenciales disimilitudes. Buenos Aires: Cooperadora de Derecho y Ciencias Sociales, 1976.
} 


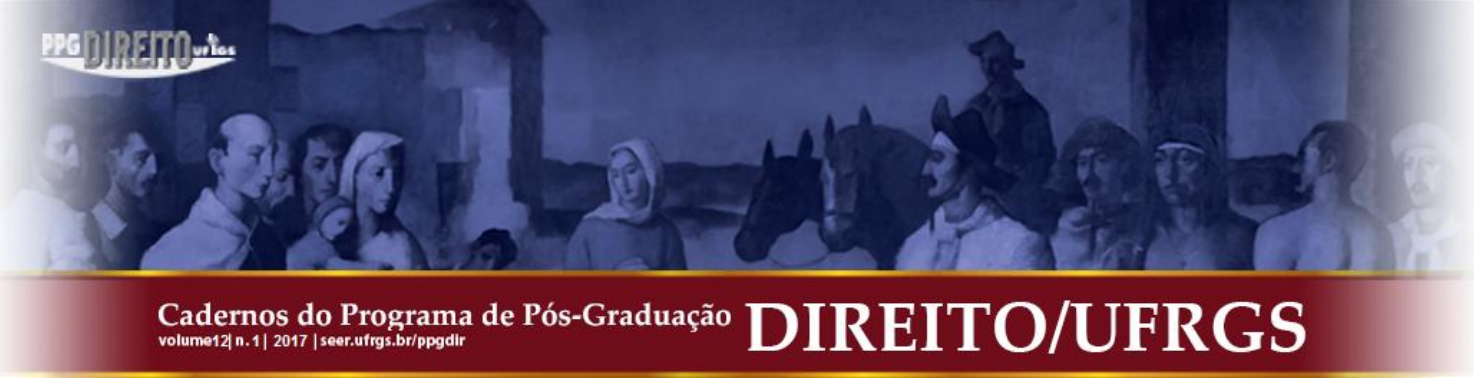

confederação helvética, a confederação norte-americana... -, sublinham as questões de defesa e de política econômica na origem das confederações. Assim como um de seus traços característicos assinalado pela maioria dos autores que se ocupam do tema é que os Estados membros de uma confederação retêm sua soberania externa ${ }^{65}$.

Esta característica de estar formada por Estados independentes, própria da confederação, encontramo-la tanto nos tratadistas contemporâneos como anteriormente em Montesquieu ou n'O Federalista. Montesquieu julgava que a confederação era uma forma apropriada de governo que reunia as vantagens interiores do republicanismo e as exteriores do regime monárquico, e se referia a ela - em sua linguagem, a república federativa - como "uma sociedade constituída por outras sociedades", e a seus membros mediante conceitos como "corpos políticos", "sociedades", "pequenas repúblicas" etc. ${ }^{66}$. O Federalista, citando Montesquieu, definia a confederação - a "república confederativa" - "como "uma reunião de sociedades' ou como a associação de dois ou mais Estados em um só". Quanto às modalidades do Estado confederado, observa na continuação que: “a amplitude, modalidades e objetos da autoridade federal são puramente discricionários. Porém, enquanto subsista a organização separada de cada um dos membros" (...) "seguirá sendo, tanto de fato como em teoria, uma associação de Estados, ou seja, uma confederação",67.

\section{O CASO RIO-PLATENSE: CONFEDERAÇÃO DE “PROVÍNCIAS”?}

Retornando ao nosso assunto, o surpreendente é que este critério do atual direito político que distingue os conceitos de federação e confederação como correspondentes a duas distintas formas de organização política, esta noção da distinta natureza de uma confederação e de um Estado federal, não impeça de seguir englobando as expressões da política antimonárquica e antiunitária posteriores à independência na comum denominação de federalismo. Porque, da adequada compreensão da diferença que ambas as formas supõem, infere-se a distinta natureza das unidades políticas participantes do processo histórico posterior à independência. Isto é, se do que se tratava era uma confederação, então seus

\footnotetext{
${ }^{65}$ Este traço, inexistente na Confederação Argentina surgida do Pacto Federal de 1831, outorga-lhe um cariz peculiar.

${ }^{66}$ MONTESQUIEU. op. cit., p. 91.

${ }^{67}$ HAMILTON; MADISON; JAY. op. cit., p. 35.
} 
protagonistas, a que nós chamamos de províncias, não podiam ser outra coisa senão Estados livres e soberanos, com plena independência em termos de direito internacional.

A confusão pode ser atribuída ao fato de que a dificuldade apresentada pelo caso platino, e que pode explicar a renúncia a reconhecer a distinção confederação/Estado federal, é a da natureza jurídico-política das partes confederadas, que no caso foram as denominadas "províncias". Pois não pode menos do que chamar a atenção o fato de não se haver reparado no anômalo de uma confederação - reunião de Estados independentes - criada por "províncias" - por definição, partes de outro Estado que as engloba ${ }^{68}$.

Por exemplo, Juan A. González Calderón - destacado historiador constitucionalista da primeira metade do séc. XX - percebe com clareza a natureza jurídica que as partes signatárias do Pacto Federal de 1831 possuíam. Segundo esse autor, este pacto, o "estatuto fundamental" ou "lei fundamental" da Confederação Argentina, que foi o acordo mais importante concertado pelas províncias platinas desde 1810 com o propósito de alcançar a organização constitucional que as unisse em um Estado nacional, cumpriu o mesmo papel que os "Artigos de Confederação e União Perpétua" dos Estados Unidos, com os quais tem muitas similitudes $^{69}$. Seguindo a outro dos principais constitucionalistas argentinos, Luis V. Varela, González Calderón observa que o regime de confederação vigente desde então foi exercido com amparo na doutrina constitucional norte-americana do período 1778-87 ou à germânica de $1815^{70}$. E, quanto à entidade das partes confederadas, sustenta:

Entre a situação dos Estados norte-americanos confederados (1778-1787) e a das províncias argentinas confederadas (1831-1852) há grande analogia, ainda que não haja identidade. A comparação pode ser feita sem exagerar a concordância. Desde logo, o fundamento, a base, dessas duas confederações foi o pacto, o que significa que as partes contratantes, Estados ou Províncias, eram entidades jurídicas com absoluta capacidade ou plenitude de poder para obrigarem-se, e delegarem voluntariamente a uma autoridade comum os direitos e atribuições cujo exercício particular não lhes convinha reservar ${ }^{71}$.

\footnotetext{
${ }^{68}$ Também é o caso da Holanda após a dominação espanhola. Assim, Montesquieu alude à confederação formada por Estados e províncias, sem comentário a respeito (MONTESQUIEU. op. cit., p. 91 et seq.). Esta circunstância possivelmente contribuiu para que os tratadistas argentinos não se aprofundassem no problema. Cabe observar, no caso holandês, que a denominação de províncias era também um hábito remanescente da recente dominação dos Habsburgos.

${ }^{69}$ GONZÁLEZ CALDERÓN, Juan A. op. cit., 1930, 184 et seq.

${ }^{70}$ GONZÁLEZ CALDERÓN, Juan A. op. cit., 1930, p. 187.

${ }^{71}$ GONZÁLEZ CALDERÓN, Juan A. op. cit., 1930, p. 187. Entre as diferenças, há uma "importante e profunda": os Artigos norte-americanos instituíram um Congresso como poder central, enquanto que, no caso argentino, uma Comissão Representativa, que foi dissolvida em pouco tempo e substituída, só no relativo às relações exteriores e a 
Apesar disso, o autor não extrai tudo o que naturalmente decorre de seu ponto de vista. Não deixa de considerar a natureza das entidades constituintes da Confederação de 1831 como a de províncias, cuja índole estatal designa com as palavras autonomia ou independência, porém sem afrontar, em momento algum, o que se seguiria de reconhecer nas partes que se confederam a plena natureza de Estado. Mais ainda, retrocedendo em certo momento, ao afirmar que "(...) cada uma era uma entidade quase-soberana (...)"72.

Entretanto, como já advertimos, a questão não havia deixado de ser percebida no curso dos intentos constitucionais da primeira metade do século. Assim, possuímos alguns testemunhos que mostram a distinção, bem como a correlação implicada nos pares conceituais província/Estado e federação/confederação, a qual não havia sido ignorado nos anos posteriores à independência. Vejamos, por exemplo, a breve interrupção de um deputado no curso de um debate do Congresso Constituinte sobre o nome da futura nação, em janeiro de 1825 - texto no qual a palavra "federação" equivale, na realidade, a "confederação", segundo o já exposto sobre o uso desse termo à época:

Caso se considere que se há de estabelecer um sistema de unidade, estará bem a aprovação desta denominação de Províncias Unidas etc., pois as províncias são departamentos subordinados a um centro de unidade; mas, se se adota o sistema de federação, serão Estados e não províncias; portanto, creio que, sancionando-se como está, deveria ser deixando-se a reserva de variar a palavra províncias no lugar de Estados, se se houvesse de adotar o sistema de federação.

Esta observação é compartilhada por outro deputado, que, ao expressar seu critério, também usa a palavra "federação" no sentido indicado: “(...) certamente, se por convênio ou convencimento das províncias que formam o Estado, vem a resultar que a forma de governo que se adota seja a de federação, o nome Províncias Unidas não ficará bem, e deverá ser Estados Unidos"73.

assuntos de paz e guerra, pelo Governador de Buenos Aires (GONZÁLEZ CALDERÓN, Juan A. op. cit., 1930, p. 188).

${ }^{72}$ GONZÁLEZ CALDERÓN, Juan A. op. cit., 1930, p. 189.

73 RAVIGNANI, Emilio (Org.). Asambleas Constituyentes argentinas. Tomo I. Buenos Aires: Instituto de Investigaciones Históricas de la Facultad de Filosofía y Letras - Universidad de Buenos Aires, 1937, p. 1026. 


\section{TESTEMUNHOS SIGNIFICATIVOS}

A qualidade de Estados independentes que as províncias platinas possuíram foi percebida por observadores da época que não podiam se enganar a respeito. Vários textos, um de uma etapa inicial e os outros do final do período, merecem destaque. O primeiro deles pertence a Juan Manuel de Rosas, que expressava seu desgosto com o tratado subscrito pelas províncias do Litoral, a 31 de janeiro de 1831: “Concluiu-se o tratado e não tive um momento de ilusão (...). (...) As províncias vieram realmente a ser estados diferentes, e se não se busca outro fundamento que os que até agora foram colocados em prática, jamais se ligarão"74.

Esta manifestação de desgosto em relação ao que avaliava como política das outras províncias não impediu que, um pouco mais tarde, o principal porta-voz do governo de Buenos Aires, Pedro de Angelis, defendesse a mesma política como um direito dessa província: “(...) A soberania das províncias é absoluta, e não tem outros limites senão os que querem lhe prescrever seus próprios habitantes. Assim é que o primeiro passo para se reunir em corpo de nação deve ser tão libre e espontâneo como o seria para França aderir à aliança com a Inglaterra" ${ }^{, 75}$.

Esta mesma característica, no entanto, será observada, mais detalhadamente, por Juan Bautista Alberdi em 1852, após a queda de Rosas. Alberdi percebe que o regime político de cada uma das províncias argentinas depois de 1820 possuía conformação nacional. Segundo seu critério, o conjunto das províncias havia imitado à de Buenos Aires quanto ao que considera usurpar prerrogativas correspondentes à nação. O governo de Buenos Aires, organizado por Rivadavia, em 1821:

Era o primeiro governo de província que aparecia na República Argentina, organizando-se com independência, prescindindo dos demais povos e revestindo todas as formas de um governo representativo completo em seus elementos. Era um

\footnotetext{
${ }^{74}$ Rosas a García, Santa Fe, 28 de janeiro de 1831 apud NICOLAU, Juan Carlos. Correspondencia inédita entre Juan Manuel de Rosas y Manuel José García. Tandil: Instituto de Estudios Histórico-Sociales; U.C.P.B.A., 1989, p. 50 (mimeografado). Rosas expressava seu desgosto por não haver podido submeter as províncias litorais a uma organização política regida pela de Buenos Aires.

75 El Lucero (1832) apud RAVIGNANI, Emilio (Org.). Relaciones interprovinciales: La Liga Litoral (1829-1833). Documentos para la Historia Argentina. Tomo XVII. Buenos Aires: Facultad de Filosofía y Letras - Instituto de Investigaciones Históricas, 1922, p. 196 (Segundo Apêndice, doc. $\mathrm{n}^{\circ}$ 19). De Angelis respondia ao governador de Corrientes, Pedro Ferré, o qual havia criticado duramente a oposição de Buenos Aires à convocação da assembleia constituinte prevista no Tratado de 1831.
} 


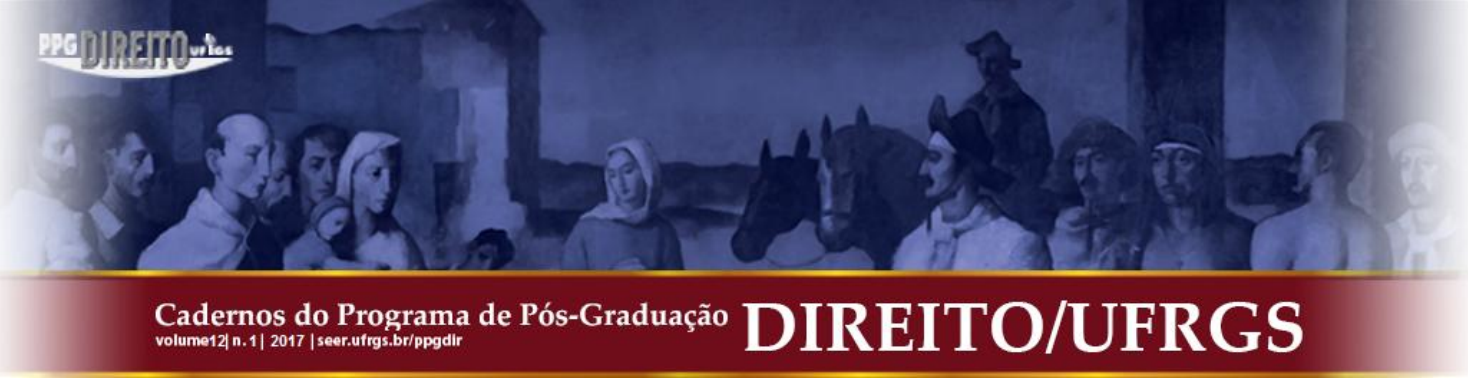

resultado de isolamento provincial consentido e confessado, consagrado como opinião triunfante e erigido em sistema de governo ${ }^{76}$.

E adiciona:

\begin{abstract}
A mera existência de catorze governos completos em seus poderes elementares só significava o desmembramento do governo nacional e a radicalização do isolamento em instituições locais permanentes; significava a criação de muitos governos isolados e independentes, vivendo nesse estado de coisas que impropriamente se chamou de federal, e dando origem à imensa dificuldade que hoje se enfrenta de recolher os poderes dispersos para formar o governo geral derrogado pelas leis locais e olvidado pelos costumes emanados dessas leis.
\end{abstract}

Essa dificuldade, insiste, é a que as províncias: “(...) hoje experimentam para desprenderem-se do uso das faculdades nacionais a que se acostumaram já pelo período de trinta anos"

Em Alberdi, há dois critérios que é preciso distinguir: um, o do caráter nacional das instituições que as províncias adotavam (a adoção de "todas as formas de um governo representativo completo"). Outro, que isso era produto do abandono de um sistema nacional preexistente:

\begin{abstract}
Até 1821 a República Argentina jamais havia conhecido outro governo que o nacional ou central: primeiramente, sob o antigo regime, o governo geral do Vicereinado do Prata, e desde 1810, com breves interregnos, o governo republicano nacional das Províncias Unidas, até 1820, no qual a Constituição unitária de 1819 deixou de ser respeitada pelos povos sublevados contra o governo central mal organizado.
\end{abstract}

Esta segunda tese, que "põe" a Nação no começo do processo, discutimo-la em outro $\operatorname{lugar}^{78}$. Interessa-nos, agora, a primeira. É dizer, como e por que Alberdi concebe que algo feito nas províncias era de índole nacional. O que foi que Buenos Aires fez, sendo imitada a seguir pelas demais províncias? "Imitou o que conhecia: copiou as atribuições do governo nacional, realista e pátrio, do qual havia sido capital [cabeza] durante dois séculos, e conferiuas a seu governo de província”.

\footnotetext{
${ }^{76}$ ALBERDI, Juan Bautista. Derecho público provincial argentino. Buenos Aires: La Cultura Argentina, 1917, p. 133 (1. ed. de 1853). Ver o parágrafo I da Segunda Parte - parte dedicada ao "Exame crítico das instituições atuais de província na República Argentina".

${ }_{77}^{17}$ ALBERDI, Juan Bautista. op. cit., p. 136 e 137.

${ }^{78}$ CHIARAMONTE, José Carlos. El mito de los orígenes en la historiografía latinoamericana. Cuadernos del Instituto Ravignani, Instituto de Historia Argentina y Americana “Dr. Emilio Ravignani”, n. 2, 1991.
} 


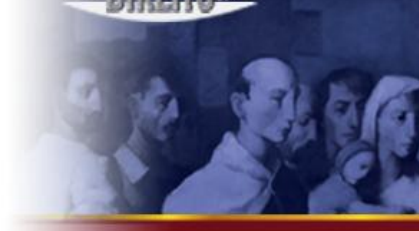

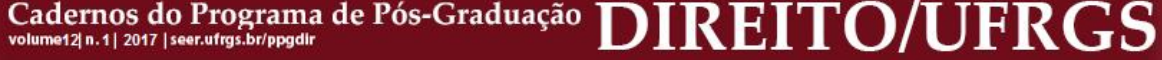

De modo que Buenos Aires, “(...) designando-se faculdades nacionais, em vez de organizar-se em província, organizou-se em nação; e as outras províncias, copiando literalmente a planta de seu governo em virtude do princípio da igualdade aceito em tratados por Buenos Aires, deram à luz catorze governos argentinos de caráter nacional em razão do nível, qualidade e extensão de seus poderes"79.

O que aqui foi expresso por Alberdi é a percepção da substância confederativa subjacente ao chamado "federalismo": o processo de formação de conatos de Estados-nação nos contornos das chamadas províncias.

As demais províncias, continua o autor das Bases..., desenvolveram uma política similar. O Estatuto provisório constitucional de Entre Ríos, de 1822, e a constituição de Corrientes, de 1824, que considera imitações da Constituição de 1819, davam a essas províncias faculdades de nação. A legislação da província de Mendoza, antes de sua Constituição formal, também assumia atribuições nacionais ${ }^{80}$.

De sua parte, num libro publicado em 1850, Sarmiento oferece-nos um notável testemunho desta situação política do Rio da Prata ao finalizar a primeira metade do século. Em Argirópolis, observamos que o autor do Facundo não enxerga melhor perspectiva que a de unir toda a região em uma confederação, perspectiva que mais tarde, uma vez alcançada a união federal de 1853, rechaçará vigorosamente. Porém, quando escreve Argirópolis, sua perspectiva não ia mais além da forma confederativa, pois propunha uma Confederação formada por cada província das que então integravam a Confederação Argentina, junto ao Uruguai e ao Paraguai, e cuja capital seria na ilha de Martín García. Trata-se de uma fórmula que consulta, afirmava,

(...) os interesses de cada uma das províncias que formam a Confederação Argentina, os da República do Uruguai e os do Paraguai, todas e cada uma interessadas em estabelecer um regramento para suas relações comerciais, navegação de seus rios e sua independência recíproca, sem sacrificar os interesses de todas as províncias pelo de uma delas, nem o de todos os Estados partícipes pelo de um só ${ }^{81}$

\footnotetext{
${ }^{79}$ ALBERDI, Juan Bautista. op. cit., p. 133, 137 e 138. Alberdi julga a partir desse critério a política de Buenos Aires logo da organização constitucional: "Antes eram suas leis avulsas de caráter constitucional as depositárias desses princípios de dissolução do governo nacional argentino; hoje, o é sua Constituição moderna de Província-Estado, na qual refundiu essas leis de desordem para levar adiante, como de há trinta anos, o sistema de estorvar e contrariar a instituição de um governo comum a todas as províncias, a fim de que não passem às mãos deste os poderes e rendas nacionais de que Buenos Aires desfrutou por abuso" (Ibidem. p. 150).

${ }^{80}$ ALBERDI, Juan Bautista. op. cit., p. 186, 188, 190 e 191.

${ }^{81}$ SARMIENTO, Domingo F. Argirópolis [o la capital de los estados confederados del Río de la Plata]. Buenos Aires: La Cultura Argentina, 1916, p. 75 e 69 (1. ed. de 1850).
} 
Aparentemente, a partir da interpretação que então fazia da realidade platina, Sarmiento parecia resignar-se com o caminho confederativo como perspectiva imediata. Poucos anos depois, em 1853, em seus Comentarios a la Constitución..., obra que teve maior influência, afastará a possibilidade de interpretar a Constituição de 53 em termos confederativos, variante que repudia firmemente ${ }^{82}$.

Deste modo, o processo que se prolonga desde os começos do movimento de independência platina, em 1810, até a constituição de um Estado federal argentino, em 1853, verá a sucessão de duas "soberanias" distintas: a das cidades, primeiro; a das províncias, depois. Províncias que ao constituírem a Confederação de 1831, limitaram a delegação, transitória, de soberania à representação exterior pelo Governador de Buenos Aires.

O caráter soberano das cidades e, logo depois, das províncias teve expressão em um traço central da vida política do período, qual seja, o tipo de representação: em todas as reuniões para tentar organizar constitucionalmente um novo Estado, ou para regular assuntos diversos entre algumas das províncias platinas, os deputados das cidades ou das províncias tinham caráter de apoderados, à semelhança dos "procuradores" do Antigo Regime espanhol. Em que pese os intentos, desde cedo, para converter esses apoderados em "deputados da nação" - o primeiro deles registrado já na Assembleia do ano XIII -, o mandato imperativo prevaleceu nesse tipo de reuniões até 1852, quando a reunião dos governadores argentinos, cujas resoluções são conhecidas como Acordo de São Nicolau, desterrou definitivamente essa prática ao proscrevê-la para o Congresso constituinte em elaboração ${ }^{83}$. Se os deputados das províncias deixaram de ser apoderados em algum momento, foi para converterem-se em "agentes diplomáticos", como quando, na esteira do fracasso constitucional de 1826, as províncias se assumem como sujeitos de direito internacional.

A decisão de ajustar explicitamente suas relações ao direito internacional em nenhum lugar ganhou mais força do que na própria Buenos Aires, em cuja Junta de Representantes se sublinhou essa realidade por parte do membro da Comissão encarregada de examinar o Tratado de 1831 para sua ratificação: “(...) a comissão, ao considerar o presente tratado, não havia perdido de vista que os povos da República, em seu atual estado de independência

${ }^{82}$ SARMIENTO, Domingo F. op. cit., 1948, p. 55 et seq.

83 A respeito desta questão fundamental, $c f$. nosso trabalho já citado: CHIARAMONTE, José Carlos. El federalismo argentino en la primera mitad del siglo XIX. In: CARMAGNANI, Marcello (Coord.). Federalismos latinoamericanos: México/Brasil/Argentina. México: El Colegio de México; F.C.E., 1993. 
. El federalismo argentino en la primera mitad del siglo XIX. In: CARMAGNANI, Marcello (Coord.). Federalismos latinoamericanos: México/Brasil/Argentina. México: El Colegio de México; F.C.E., 1993.

El mito de los orígenes en la historiografía latinoamericana. Cuadernos del Instituto Ravignani, Instituto de Historia Argentina y Americana “Dr. Emilio Ravignani”, n. 2, 1991.

. Formas de economía y sociedad en Iberoamérica. México: Grijalbo, 1984.

. La antigua Constitución luego de las independencias, 1808-1852. Desarrollo Económico, Buenos Aires, v. 50, n. 199, out.-dez. 2010.

. Legalidad constitucional o caudillismo: el problema del orden social en el surgimiento de los estados autónomos del Litoral argentino en la primera mitad del siglo XIX. Desarrollo Económico, Buenos Aires, v. 26, n. 102, jul.-set. 1986.

. Los diplomáticos del Río de la Plata. Ñ, Revista de Cultura, 2 de maio de 2015.

. The "Ancient Constitution" after the Independences (1808-1852). American Historical Review, v. 90, n. 3, ago. 2010.

DEMICHELI, Alberto. Formación constitucional rioplatense. Tomo I. Montevideo: Depalma, 1955.

. Formación constitucional rioplatense. Tomo II. Montevideo: Depalma, 1955.

FERRÉ, Pedro. Memoria del brigadier general Pedro Ferré: octubre de 1821 a diciembre de 1842. Buenos Aires: Coni, 1921.

GACETA. Artigo "sobre federaciones". 30/III/1815.

GAZETA. 25 de outubro de 1810.

GAZETA de Buenos-Ayres. 14 de fevereiro de 1811.

GOLDMAN, Noemí. Legalidad y legitimidad en el caudillismo. Juan Facundo Quiroga y La Rioja en el Interior rioplatense (1810-1835). Boletín del Instituto de Historia Argentina y Americana "Dr. Emilio Ravignani", 3" série, n. 7, 1993.

GÓMEZ, Hernán F. Bases del Derecho Público correntino. Corrientes: Impr. del Estado, 1915. . Historia de la Provincia de Corrientes: desde el tratado del Cuadrilátero a Pago Largo. Corrientes: Impr. del Estado, 1929. 


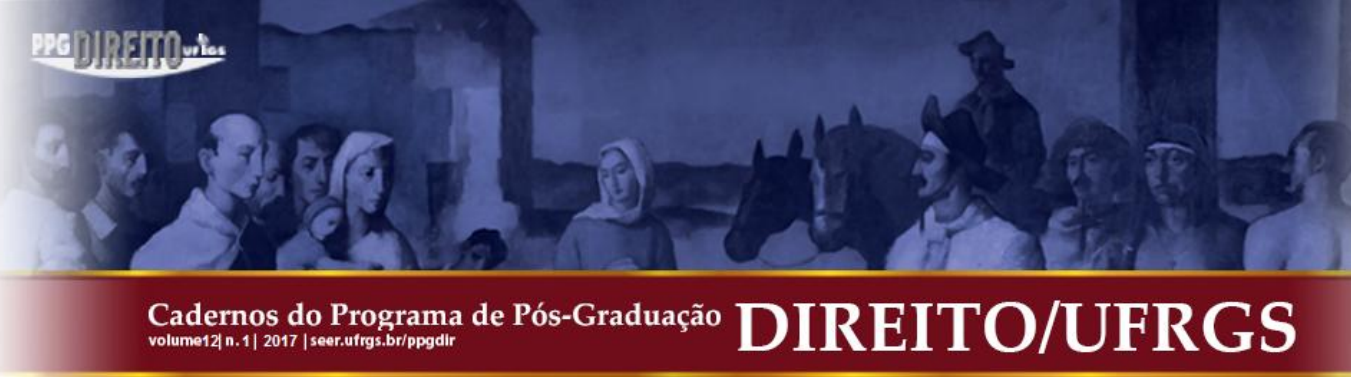

GONZÁLEZ CALDERÓN, Juan A. Derecho constitucional argentino: Historia, teoría y jurisprudencia de la Constitución. Tomo I. Buenos Aires: Lajouane, 1930.

Introducción al derecho público provincial. Buenos Aires: Lajouane, 1913.

HAMILTON, Alexander; MADISON, James; JAY, John. El Federalista. México: F.C.E., 1974.

HISTORIA de la Nación Argentina. 3. ed. v. VII. Primera Sección. Buenos Aires: Academia Nacional de la Historia, s.d.

LEVENE, Ricardo. Las Provincias Unidas del Sud en 1811 (Consecuencias inmediatas de la Revolución de Mayo). Buenos Aires: Universidad de Buenos Aires, 1940.

Plata, 1933.

Los primeros documentos de nuestro federalismo político. Humanidades, t. XXIII, La

LEY Constitucional, sancionada por el Congreso para el gobierno de la Provincia de Corrientes. Seção II, Art. 11, R.O.P.C., I.

LÓPEZ, Lucio V. Curso de Derecho Constitucional: Extracto de las conferencias dadas en la Universidad de Buenos Aires. v. I. Buenos Aires, 1891.

MONTESQUIEU. Del espíritu de las leyes. Madrid: Tecnos, 1985.

NICOLAU, Juan Carlos. Correspondencia inédita entre Juan Manuel de Rosas y Manuel José García. Tandil: Instituto de Estudios Histórico-Sociales; U.C.P.B.A., 1989.

NOVÍSIMA Recopilación de las Leyes de España (Libro VII, Título III, Ley I e Ley VII; Título IV, Ley I e Ley II). Los códigos españoles concordados y anotados. 2. ed. Tomo VIII. Madrid: A. de San Martín, 1872.

PADILLA, Alberto Gabriel. La Constitución de Estados Unidos como precedente argentino. Buenos Aires: Jesús Menéndez, 1921.

PETIT MUÑOZ, Eugenio. Artigas y su ideario a través de seis series documentales. Primera Parte. Montevideo: Universidad de la República Oriental del Uruguay, Facultad de Humanidades y Ciencias, 1956.

RAMOS, Juan P. El Derecho Público de las provincias argentinas, con el texto de las constituciones sancionadas entre los años 1819 y 1913. Tomo I. Buenos Aires: Facultad de Derecho y Ciencias Sociales, 1914.

El Derecho Público de las provincias argentinas, con el texto de las constituciones sancionadas entre los años 1819 y 1913. Tomo II. Buenos Aires: Facultad de Derecho y Ciencias Sociales, 1916. 


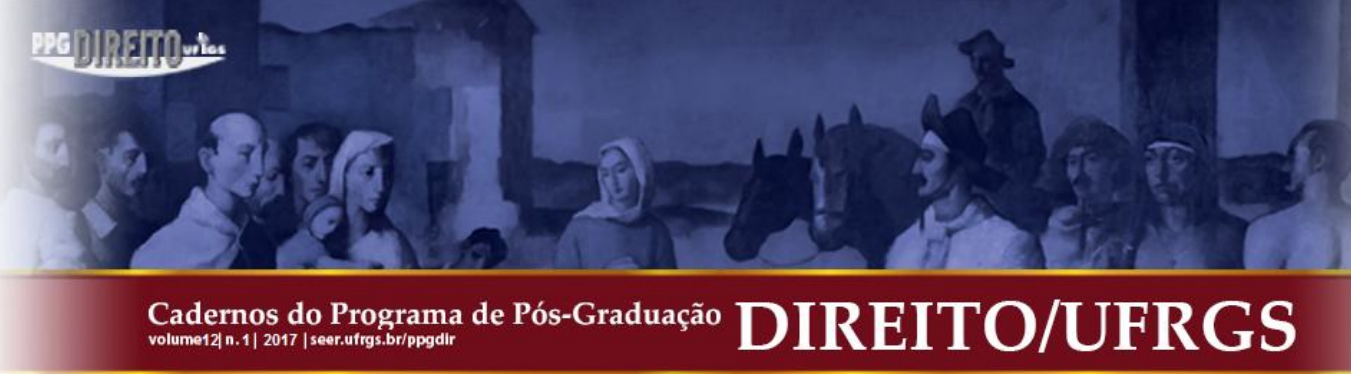

. El Derecho Público de las provincias argentinas, con el texto de las constituciones sancionadas entre los años 1819 y 1913. Tomo III. Buenos Aires: Facultad de Derecho y Ciencias Sociales, 1916.

RAVIGNANI, Emilio. "El Congreso nacional de 1823-1827, La Convención nacional de 18241829, Inconstitución y régimen de pactos". Historia de la Nación Argentina. 3. ed. v. VII, Primera Sección. Buenos Aires: Academia Nacional de la Historia, [s.d.].

1927.. Historia Constitucional de la República Argentina. Tomo II. Buenos Aires: Peuser,

Un proyecto de Constitución relativo a la autonomía de la Provincia Oriental del Uruguay, 1813-1815. Buenos Aires: Impr. de la Universidad de Buenos Aires, 1929.

RAVIGNANI, Emilio (Org.). Asambleas Constituyentes argentinas. Tomo I. Buenos Aires: Instituto de Investigaciones Históricas de la Facultad de Filosofía y Letras - Universidad de Buenos Aires, 1937.

. Asambleas Constituyentes argentinas. Tomo VI. Buenos Aires: Instituto de Investigaciones Históricas de la Facultad de Filosofía y Letras - Universidad de Buenos Aires, 1937.

. Relaciones interprovinciales: La Liga Litoral (1829-1833). Documentos para la Historia Argentina. Tomo XVII. Buenos Aires: Facultad de Filosofía y Letras - Instituto de Investigaciones Históricas, 1922.

RECOPILACIÓN de Leyes, Decretos y Acuerdos de la Provincia de Entre Ríos, desde 1821 a 1873. Tomo I- 1821 a 1824.

REGISTRO Diplomático del Gobierno de Buenos-Aires. Buenos Aires: Imprenta del Estado, 1835 .

REGISTRO Oficial de la Provincia de Corrientes. Ley n ${ }^{\circ}$ 1, 26/XI/1821. Tomo I, [s.d].

REGISTRO Oficial de la Provincia de Santa Fe. 1815 al año 1817. Tomo I. Santa Fe, 1888.

REGISTRO Oficial de la República Argentina. Tomo I, 1810 a 1821. Buenos Aires, 1879.

REGLAMENTO constitucional para la nueva provincia de Catamarca, dado por su asamblea de 11 de julio de 1823. In: RAMOS, Juan P. El Derecho Público de las provincias argentinas, con el texto de las constituciones sancionadas entre los años 1819 y 1913. Tomo I. Buenos Aires: Facultad de Derecho y Ciencias Sociales, 1914.

REGLAMENTO para la organización política de la provincia de Santiago del Estero (...), 26 de julio de 1830. In: RAVIGNANI, Emilio (Org.). Asambleas Constituyentes Argentinas. Tomo VI. Buenos Aires: Instituto de Investigaciones Históricas de la Facultad de Filosofía y Letras Universidad de Buenos Aires, 1937. 


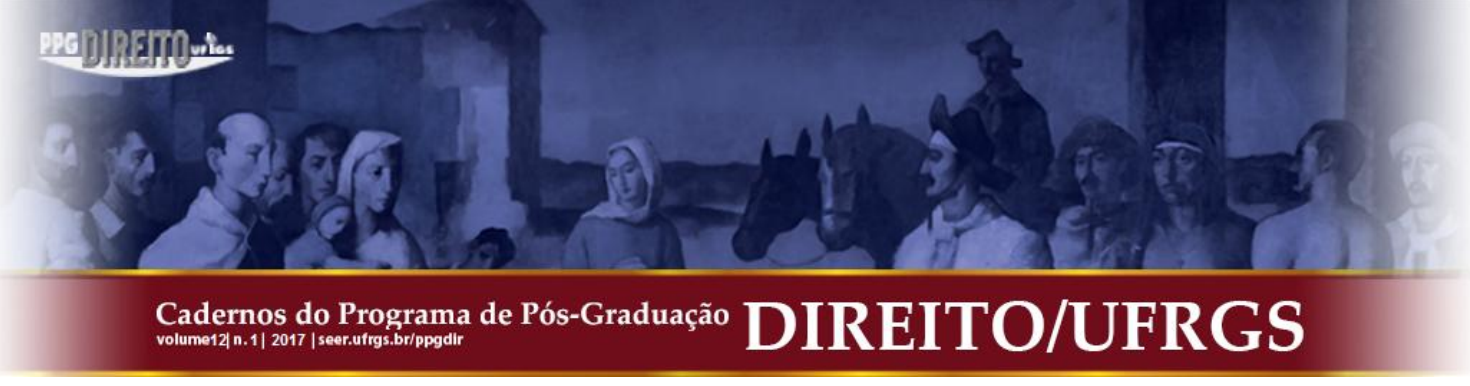

REGLAMENTO provisional de Gobierno para los Pueblos de Cuyo, 1821. In: RAVIGNANI, Emilio (Org.). Asambleas Constituyentes argentinas. Tomo VI. Buenos Aires: Instituto de Investigaciones Históricas de la Facultad de Filosofía y Letras - Universidad de Buenos Aires, 1937.

REGLAMENTO provisorio de la provincia de Córdoba para el régimen de las autoridades de ella, expedido el 30 de enero de 1821. In: RAMOS, Juan P. El Derecho Público de las provincias argentinas, con el texto de las constituciones sancionadas entre los años 1819 y 1913. Tomo I. Buenos Aires: Facultad de Derecho y Ciencias Sociales, 1914.

SARMIENTO, Domingo F. Argirópolis [o la capital de los estados confederados del Río de la Plata]. Buenos Aires: La Cultura Argentina, 1916.

SARMIENTO s Domingo F. Comentarios de la Constitución. Buenos Aires: Luz del Día, 1948.

. Comentarios de la Constitución de la Confederación Argentina. Santiago de Chile:

Imprenta de Julio Belín y Ca., septiembre de 1853.

SOSA, Ismael. Historia constitucional del Tucumán. Tucumán: Universidad Nacional de Tucumán - Facultad de Derecho y Ciencias Sociales, 1945.

SPOTA, Alberto Antonio. Confederación y estado federal: Conceptos y esenciales disimilitudes. Buenos Aires: Cooperadora de Derecho y Ciencias Sociales, 1976.

TEDESCHI DE BRUNET, Sonia. Los últimos años de una institución colonial: el Cabildo de Santa Fe y su relación con otros espacios político-institucionales entre 1819 y 1832. Revista de la Junta Provincial de Estudios Históricos de Santa Fe, n. LIX, 1993.

TOCQUEVILLE, Alexis de. La democracia en América. México: F.C.E., 1957.

VANOSSI, Jorge R. El estado de derecho en el constitucionalismo social. 2. ed. Buenos Aires: Eudeba, 1987.

VANOSSI, Jorge R. La influencia de la Constitución de los Estados Unidos de Norteamérica en la Constitución de la República Argentina. Revista Jurídica de San Isidro, dez. 1976.

. Situación actual del federalismo. Buenos Aires: Depalma, 1964.

VERDÚ, Pablo Lucas. Confederación. In: MASCAREÑAS, Carlos E. (Coord.). Nueva

Enciclopedia Jurídica. Tomo IV. Barcelona: Francisco Seix, 1952.

Submissão: 23/08/2017

Aceito para Publicação: 30/08/2017 


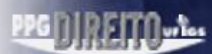

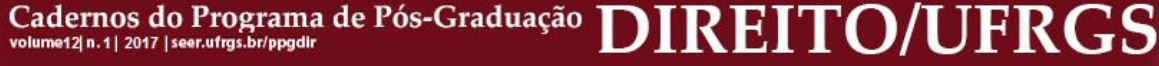

